\title{
Clostridial binary toxins: iota and C2 family portraits
}

\author{
Bradley G. Stiles ${ }^{1,2}$ *, Darran J. Wigelsworth ${ }^{2}$, Michel R. Popoff $^{3}$ and Holger Barth ${ }^{4}$. \\ Biology Department, Wilson College, Chambersburg, PA, USA \\ 2 Integrated Toxicology Division, Medical Research Institute of Infectious Diseases, Frederick, MD, USA \\ ${ }^{3}$ CNR Anaerobies, Institut Pasteur, Paris, France \\ ${ }^{4}$ Institute of Pharmacology and Toxicology, University of UIm Medical Center, UIm, Germany
}

\section{Edited by:}

Ken Bradley, University of California

Los Angeles, USA

Reviewed by:

Vincent Joseph Starai, The University of Georgia, USA

Chengzhi Wang, Cancer Research

Center, USA

*Correspondence:

Bradley G. Stiles, Biology

Department, Wilson College, 1015

Philadelphia Avenue, Chambersburg,

PA 17201, USA.

e-mail: bstiles@wilson.edu

Holger Barth, Institute of

Pharmacology and Toxicology,

University of UIm Medical Center,

Albert-Einstein Allee 11, D-89081

Ulm, Germany.

e-mail:holger.barth@uni-ulm.de
There are many pathogenic Clostridium species with diverse virulence factors that include protein toxins. Some of these bacteria, such as $C$. botulinum, C. difficile, C. perfringens, and $C$. spiroforme, cause enteric problems in animals as well as humans. These often fatal diseases can partly be attributed to binary protein toxins that follow a classic AB paradigm. Within a targeted cell, all clostridial binary toxins destroy filamentous actin via mono-ADPribosylation of globular actin by the A component. However, much less is known about B component binding to cell-surface receptors. These toxins share sequence homology amongst themselves and with those produced by another Gram-positive, spore-forming bacterium also commonly associated with soil and disease: Bacillus anthracis. This review focuses upon the iota and C2 families of clostridial binary toxins and includes: (1) basics of the bacterial source; (2) toxin biochemistry; (3) sophisticated cellular uptake machinery; and (4) host-cell responses following toxin-mediated disruption of the cytoskeleton. In summary, these protein toxins aid diverse enteric species within the genus Clostridium.

Keywords: actin, Bacillus, Clostridium, protein toxins

\section{BASICS OF THE BACTERIAL PLAYERS}

Species of Clostridium (derived from Greek "kloster"= spindle) are ubiquitous, anaerobic, spore-forming bacilli of the phylum Firmicutes (Latin "firmus" = strong and "cutis" = skin). These bacteria are commonly found throughout the world in soil, water, and gastrointestinal tracts of animals as well as humans. The $\mathrm{G}+\mathrm{C}$ content of the genus ranges from 22 to $52 \%$, with the majority around 28\% (Jones and Keis, 2005). Many clostridia are harmless and quite versatile for solvent production (i.e., acetone, butanol, isopropanol from $C$. acetobutylicum and C. beijerinckii), nitrogen fixation (C. pasteurianum), biodegradation of natural polymers (cellulose, pectin, etc.) or hazardous materials (TNT, chlorinated solvents, etc.), debridement of necrotic tissue (application of collagenase from $C$. histolyticum), and novel anti-cancer treatments (C. novyi, etc.). However, there are notable exceptions and some of these clostridial pathogens for various mammals are presented in this review (Dürre, 2005; Songer, 2005).

Some Clostridium and related Bacillus species have developed common mechanisms for survival within, and outside of, numerous hosts. This is evidenced by the various diseases caused by these microorganisms that are often mediated by protein toxins, enzymes, and spores. C. botulinum, C. difficile, C. perfringens, as well as $C$. spiroforme are collectively associated with a multitude of animal and human diseases/intoxications such as gas gangrene, food poisoning, antibiotic-associated diarrhea, pseudomembranous colitis, and enterotoxemia. Anthrax attributed to B. anthracis also occurs in different mammals, and includes three forms: (1) cutaneous; (2) intestinal; and (3) inhalational. An ability to survive and thrive in diverse niches is a remarkable characteristic of these spore-forming bacteria. This review particularly focuses upon different aspects of the iota and C2 families of binary toxins produced by four different clostridia.

\section{CLOSTRIDIUM PERFRINGENS IOTA TOXIN}

Clostridium perfringens, previously known as Bacillus aerogenes capsulatus and later Clostridium welchii, was first described by Welch and Nuttal in 1891 (Welch and Flexner, 1896; Lucey, 2004). In particular, the bacterium was isolated following a human autopsy (death due to an aortic aneurism) with profuse gas formation throughout the circulatory system and multiple organs. Microscopic examination of organ tissues revealed bacilli masses, especially where gas pockets formed within the tissue wall. The isolate was successfully cultured in anaerobic, not aerobic, media. This bacterium was non-motile and very similar in size/shape as $B$. anthracis previously described by Robert Koch; however, it was not $B$. anthracis. There was no overt pathogenesis of this unique isolate upon intravenous injection into rabbits, but bacterial introduction immediately followed by euthanasia reproduced post-mortem findings similar to the aforementioned human case. It was concluded that growth of Bacillus aerogenes capsulatus (C. perfringens) can occur in humans, and animals, as a postmortem event. Welch and Flexner (1896) nicely describe many other human cases of $C$. perfringens-associated disease manifested as a pelvic abscess, pneumothorax, peritonitis, gas gangrene of extremities, etc. Under certain circumstances involving an anaerobic niche, many sites within the human body were recognized 120 years ago as hospitable for $C$. perfringens growth during life, and afterward in death. 
There are five toxinotypes (A-E) of C. perfringens classically based upon four lethal, dermonecrotic toxins (alpha, beta, epsilon, and iota). These "major" protein toxins are neutralized by typespecific antisera in mouse lethal and guinea-pig dermonecrotic assays. Today, multiplex polymerase chain reactions (PCR) are usually employed for rapid typing of isolates (Sawires and Songer, 2005). The iota toxin is exclusively produced by type $\mathrm{E}$ strains and implicated in sporadic diarrheic outbreaks among calves and lambs (Bosworth, 1940; Billington et al., 1998). Although C. perfringens iota toxin was initially described in 1940 by Bosworth, its binary nature was elucidated 45 years later by exploiting crossreacting antiserum against C. spiroforme (Stiles and Wilkins, 1986). The two proteins that comprise iota toxin were then designated as iota a or Ia (slow moving) and iota b or Ib (fast moving), based upon electrophoretic mobility in crossed-immunoelectrophoresis. Ia or Ib are separately non-toxic, as is the case for individual components from any toxin described in this review. However, an Ia-Ib mixture forms a potent cytotoxin that rapidly kills mice, causes dermonecrosis in guinea pigs, induces rounding of various cell types in vitro, and elicits fluid accumulation in rabbit ileal loops. Later studies revealed that Ia is a mono-ADP-ribosyltransferase specific for actin (Schering et al., 1988). Although Ib lacks discernible enzymatic activity, it binds to a cell-surface protein(s) and subsequently translocates Ia into the cytosol of a targeted cell via lipid rafts and clathrin-independent endocytosis (Stiles et al., 2000; Hale et al., 2004; Nagahama et al., 2004; Gibert et al., 2011).

Recent studies by Nagahama et al. (2011) suggest a slight paradigm shift for the clostridial binary toxins, pending cell type. For instance, they investigated the effects of Ib (no Ia) upon eight different cell lines. Although there were no effects of only Ib (high $\mathrm{ng} / \mathrm{ml}$ ) upon six lines, viability and ATP levels rapidly decreased in A431 (human epithelial carcinoma) and A549 (human lung adenocarcinoma) cells. Future experiments will surely reveal more interesting attributes of Ib, without Ia, upon cells.

\section{CLOSTRIDIUM SPIROFORME TOXIN}

Similar to the classic rod-shaped $C$. perfringens and enteric-acting iota toxin, the distinctly coiled C. spiroforme also causes diarrheic deaths that are spontaneous or antibiotic-induced in rabbits (Borriello and Carman, 1983; Carman and Evans, 1984) and perhaps humans (Babudieri et al., 1986). Although further linkage with human disease has not been confirmed, C. spiroforme was originally isolated from human feces (Kaneuchi et al., 1979), as is the closely related Coprobacillus catenaformis (Kageyama and Benno, 2000). Clearly, rabbits are very susceptible to C. spiroforme-induced diarrhea during stress involving lactation, old age, weaning, and an altered diet (Carman and Evans, 1984). This bacterium is not commonly associated with the intestinal flora of healthy animals (Borriello and Carman, 1983; Carman and Evans, 1984). Furthermore, C. spiroforme isolated from outbreaks throughout Italy have become rather resistant to antimicrobials commonly used for treating infected rabbit colonies (Agnoletti et al., 2009). This latter point raises a daunting issue of disease management in the future.

The major virulence factor produced by C. spiroforme is an iota-like toxin called CST. The Sa and Sb components of CST are respectively analogous to $\mathrm{Ia}$ and $\mathrm{Ib}$ of $C$. perfringens iota toxin, as first determined by crossed-immunoelectrophoresis and neutralization studies with $C$. perfringens type $\mathrm{E}$ antiserum (Stiles and Wilkins, 1986; Popoff et al., 1989; Simpson et al., 1989). It was erroneously thought that $C$. perfringens type E caused various diarrheic outbreaks within rabbit colonies, as type E antiserum neutralizes the cytotoxic cecal contents from enterotoxemic rabbits in vitro (Katz et al., 1978; Borriello and Carman, 1983). However, C. perfringens type $\mathrm{E}$ was never isolated and the real breakthrough came in 1983 correlating disease with enteric presence of C. spiroforme (Borriello and Carman, 1983). Spores were selected from cecal contents via heat $\left(80^{\circ} \mathrm{C} / 10 \mathrm{~min}\right)$ or ethanol $(50 \% / 1 \mathrm{~h}$ at room temperature) resistance and subsequently plated onto blood or egg yolk agar incubated anaerobically at $37^{\circ} \mathrm{C}$. Simply based upon cell morphology and arrangement, there are distinct differences between $C$. perfringens and $C$. spiroforme. There are now less laborious, PCR-based techniques for detecting C. spiroforme via ribosome- and toxin-specific genes (Drigo et al., 2008).

\section{CLOSTRIDIUM DIFFICILE TOXIN}

The final member to enter the iota family is CDT (Popoff et al., 1988; Perelle et al., 1997a). C. difficile was first recognized as a major pathogen in the 1970s regarding its role in pseudomembranous colitis and antibiotic-induced diarrhea in humans (Carroll and Bartlett, 2011). This bacterium increasingly causes many lifethreatening problems, especially in hospitals throughout the world via emerging "epidemic" strains (O'Conner et al., 2009; Kim et al., 2011).

Initial discovery and isolation of $C$. difficile (originally named Bacillus difficilis) are credited to Hall and O'Toole (1935) following studies of intestinal flora in newborn (up to 10 day old) infants. Their pioneering studies involving guinea pigs and rabbits injected with culture filtrates of $B$. difficilis ( $C$. difficile) suggested a soluble exotoxin(s). The species name is derived from the French word for "difficult," as these anaerobes did not readily ferment sugars with available techniques. Unlike adults, the intestinal tracts of infants colonized by $C$. difficile and containing large molecular-weight, Rho-glucosylating toxins A and B are interestingly not indicative of disease. In addition to humans, CDT-producing C. difficile colonize the digestive tracts of cattle (Houser et al., 2010), horses (Thean et al., 2011), and pigs (Thakur et al., 2010). Other mammals may also act as sources of $C$. difficile for human infection (Keel and Songer, 2006; Avbersek et al., 2011). C. difficile is found in commercially available meats (Gould and Limbago, 2010) and vegetables (Metcalf et al., 2010). Detection of the bacterium in clinical samples is typically done via toxins A and B (protein or DNA) assays (Barbut et al., 2011).

Like the other binary toxins, CDT consists of two components (CDTa and CDTb) that respectively share high amino acid sequence identity with $C$. perfringens Ia and Ib (Figure 1). This relatedness is further demonstrated by interchanging protein components between CDT, CST, and iota toxin (not C2 though) to form biologically active chimeras (Popoff et al., 1989; Perelle et al., 1997b; Gülke et al., 2001). Obvious structural and functional commonalities exist between these toxic proteins of $C$. difficile, C. perfringens, and C. spiroforme. It does not appear a random coincidence that these intestinal, spore-forming pathogens possess iota-family toxins. 


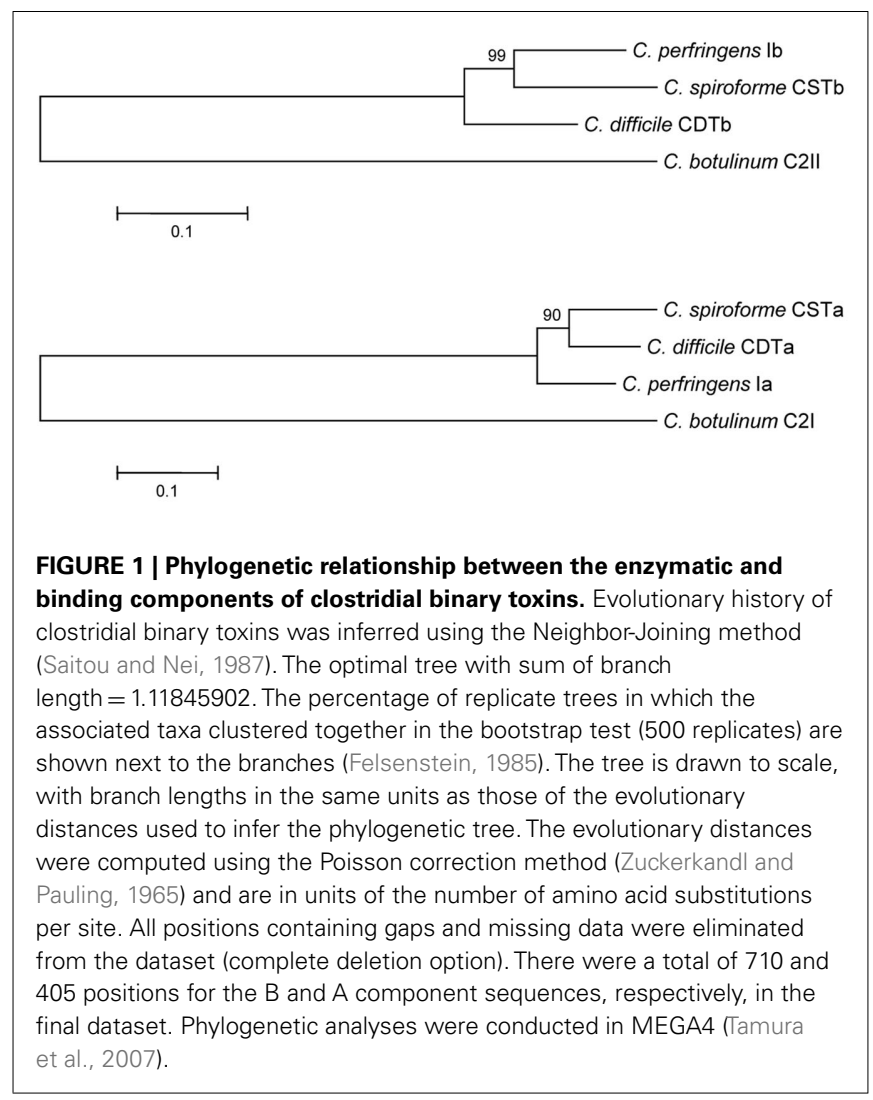

For $C$. difficile, there have been many studies among hospital patients suggesting that CDT is linked to particularly virulent, epidemic strains (Geric et al., 2003, 2006; Barbut et al., 2007; Blossom and McDonald, 2007; Miller et al., 2010; Bacci et al., 2011); however, definitive proof correlating CDT levels in feces and disease severity is lacking. In contrast, other studies do not correlate CDT with disease severity (Goldenberg and French, 2011). To help resolve this, and other, CDT-based issues a recently developed ELISA can possibly correlate binary toxin levels in feces, or from cultured isolates, to disease severity (Carman et al., 2011). When one compares the enteric/systemic effects of other clostridial binary toxins upon various mammals, quite plausibly CDT adds a synergistic or additive twist to $C$. difficile-associated disease in humans and animals. In fact, a recent Danish study by Bacci et al. (2011) suggests higher fatality rates in patients with C. difficile containing the CDT genes versus those strains without. Further correlation of CDT concentrations in the gut, and severity of $C$. difficile disease, becomes rather complicated with a sporulating bacterial pathogen that produces two other potent toxins, A and B. Add to this relative antibiotic resistance of an isolate and it becomes very difficult to unequivocally ascertain the role CDT plays in $C$. difficile disease. Perhaps use of CDT-targeted gene knockouts of $C$. difficile, with an animal infection model, could be useful for future studies (Kuehne et al., 2010)?

\section{CLOSTRIDIUM BOTULINUM C2 TOXIN}

Clostridium botulinum, initially identified as Bacillus botulinus, was first described in 1895 by Emile van Ermengem following a social gathering in Belgium where contaminated ham was served to the guests (Devriese, 1999). Some of these people died due to botulism, caused by a protein neurotoxin (BoNT). Similar to the C. perfringens typing toxins, BoNT types A-G of C. botulinum are classically determined by mouse lethal assays with BoNT-specific antisera. As with the other clostridia though, PCR-based detection is becoming more common for identifying the different toxinotypes (Fach et al., 2011).

Unlike BoNTs, the binary C2 enterotoxin produced by C. botulinum types $\mathrm{C}$ and D lacks neurotoxicity but is implicated in fatal enteric outbreaks among waterfowl. The toxin consists of C2I (enzyme) and C2II (cell-binding and translocation) proteins (Ohishi, 1983a,b), which do not complement iota-family toxin components. C2 toxin is cytopathic for many different cell types and induces vascular permeability, necrotic-hemorrhagic lesions, as well as lethal fluid accumulation into the lungs and intestinal tracts of various animals (Ohishi et al., 1980; Simpson, 1982; Ohishi and Miyake, 1985; Kurazono et al., 1987). In 1986, Aktories and co-workers discovered that C2I mono-ADP-ribosylates globular (G) actin (Aktories et al., 1986). This was the first report of any bacterial toxin that modifies actin and subsequently destroys the cytoskeleton.

\section{BIOLOGY OF CLOSTRIDIAL BINARY TOXINS}

Clostridial binary toxins are composed of enzymatic (A) and cell-binding/translocation (B) proteins released separately from the bacterium, subsequently assembling upon targeted eukaryotic cells. The iota-family members are C. difficile CDT, C. perfringens iota, and C. spiroforme CST (Table 1) based upon high sequence homology, immunological cross-reactivity, and interchangeable components that generate biologically active chimeras. The lone representative of the C2 family is from C. botulinum and distinct from the iota family in many ways (Figure 1). Interchangeable protein components of the iota-toxin family share $80-85 \%$ sequence identity, but the signal peptides are less conserved (40$61 \%$ identity). There is only $31-40 \%$ identity between C2 and iota-family toxins which is slightly higher than the $26-30 \%$ identity between $B$. anthracis protective antigen (PA) and clostridial B components. The A and B components of iota-family toxins are respectively synthesized with a leader peptide consisting of 29-49 and 39-47 residues (Popoff, 2000). In contrast, C2 toxin components are sporulation-linked and thus lack a signal peptide. These findings correlate with iota-family proteins secreted during logarithmic growth, while the $\mathrm{C} 2$ toxin is produced during sporulation (late logarithmic) and released after sporangium lysis (Nakamura et al., 1978). Various commonalities between clostridial and bacillus binary toxins, along with production of spores, suggest overlapping evolutionary paths between these genera.

The $\mathrm{AB}$ components of all Clostridium binary toxins are encoded by distinct genes possessing $27-31 \% \mathrm{G}+\mathrm{C}$ content (Popoff, 2000). The A and B genes are transcribed in the same orientation from a common operon. The A gene is located $40-50$ nucleotides upstream of the $\mathrm{B}$, with an exception being the $\mathrm{C} 2$ genes separated by 247 nucleotides (Perelle et al., 1993; Fujii et al., 1996; Gibert et al., 1997; Kimura et al., 1998). There are also other genetic differences as C. difficile CDT and C. spiroforme CST are chromosome-encoded versus the plasmid-localized C. botulinum 
Table 1 | Clostridial binary toxins.

\begin{tabular}{|c|c|c|}
\hline $\begin{array}{l}\text { Toxin and components } \\
\text { (kDa) }\end{array}$ & Gene location & Associated disease \\
\hline \multicolumn{3}{|l|}{ C. PERFRINGENS IOTA } \\
\hline $\begin{array}{l}\text { la (45) } \\
\text { lb (94 precursor/ } \\
81 \text { activated) }\end{array}$ & Plasmid & Calf/lamb enterotoxemia \\
\hline \multicolumn{3}{|l|}{ C. SPIROFORME CST } \\
\hline $\begin{array}{l}\text { Sa ( } 44) \\
\text { Sb ( } 92 \text { precursor/ } \\
76 \text { activated) }\end{array}$ & Chromosome & $\begin{array}{l}\text { Rabbit enteritis/potential rare } \\
\text { cases in humans }\end{array}$ \\
\hline \multicolumn{3}{|l|}{ C. DIFFICILE CDT } \\
\hline $\begin{array}{l}\text { CDTa (48) } \\
\text { CDTb (99 precursor/ } \\
75 \text { activated) }\end{array}$ & Chromosome & $\begin{array}{l}\text { Additional virulence factor in } \\
\text { pseudomembranous colitis/ } \\
\text { post-antibiotic enteritis }\end{array}$ \\
\hline \multicolumn{3}{|l|}{ C. BOTULINUM C2 } \\
\hline $\begin{array}{l}\text { C2I (49) } \\
\text { C2II (80 or } 100 \text { precur- } \\
\text { sor/60 or } 80 \text { activated) }\end{array}$ & Large plasmid & Avian hemorrhagic enteritis \\
\hline
\end{tabular}

C2 and C. perfringens iota toxins (Popoff, 2000; Li et al., 2007; Sakaguchi et al., 2009). Originally, the C. botulinum C2 toxin genes were thought to be chromosomal but later studies revealed a quite large $(107 \mathrm{~kb})$ plasmid with 123 potential open reading frames (Sakaguchi et al., 2009). Plasmid from C. perfringens type E that contains the iota-toxin genes is also unique in that it can encode another toxin, C. perfringens enterotoxin, which is: (1) associated with human food poisoning; (2) sporulation-linked; and (3) possesses a different mode of action versus the clostridial binary toxins (Miyamoto et al., 2011). Additionally, these type E strains can be mistyped as $C$. perfringens type A due to sequence variability within the Ia gene that is typically targeted by PCR.

\section{STRUCTURE AND FUNCTION OF B COMPONENTS}

As Table 1 shows for each toxin, the cell-binding B components are produced as precursors activated outside of the bacterium by various serine-type proteases from bacteria, the mammalian host, or that added in vitro. The resultant loss of an $\mathrm{N}$-terminal peptide $(\sim 20 \mathrm{kDa}$ ) evidently induces conformational changes that facilitate homoheptamerization, either in solution or on the cell surface. The B oligomers bind to cell-surface receptors, form complexes with respective A component(s), facilitate internalization, and ultimately release A into the cytosol. There is no enzymatic activity attributed to B components from any clostridial binary toxin.

It was initially reported in 1949 that iota toxin requires proteolytic activation for mouse lethal and guinea-pig dermonecrotic effects (Ross et al., 1949). Additional clues were provided years later, revealing that an Ib precursor (designated as Ibp) was the target of exogenously added, or culture-derived, serine-type proteases (Barth et al., 2004). Trypsin proteolysis of fractionated, early cultures of $C$. perfringens type $E$ increased ELISA readings for Ibp but not Ia. These findings suggest a conformational change in "activated" Ibp exposing cryptic epitopes recognized by Ib-specific antibodies. There was also increased guinea-pig dermonecrosis and mouse lethality of Ibp, following proteolysis, in conjunction with untreated Ia. Subsequent cloning and sequencing revealed proteolysis of Ibp near A 211 (Perelle et al., 1993), which promotes oligomerization of Ib into SDS-stable heptamers on cell membranes and lipid rafts (Hale et al., 2004; Nagahama et al., 2004); however, Ib heptamers formed in solution are rather unstable (Blöcker et al., 2001; Nagahama et al., 2002; Stiles et al., 2002). Vero cell-bound Ibp does not form oligomers and is not activated over time in vitro with, or without, exogenous trypsin or chymotrypsin (Stiles et al., 2002). The cell-targeting domain of Ib/Ibp is in the $\mathrm{C}$-terminus and quite distal from the $\mathrm{N}$-terminal activation site. To date, activation and cell-binding studies similar to those for Ib have not been conducted with $C$. difficile CDTb or C. spiroforme $\mathrm{Sb}$; however, there are likely many similarities in the biology of these B components based upon sequence homology with Ib.

Following proteolysis of Ibp, Ia readily docks with the Ib oligomer (Stiles et al., 2000). There are also voltage-dependent, ion-permeable channels formed in artificial lipid membranes by Ib oligomers, but not Ibp monomers (Knapp et al., 2002). These channels are blocked by Ia. Ib oligomers formed in solution are structurally fragile and upon binding to Vero cells do not cause potassium release, are readily digested by pronase, and do not promote Ia-induced cytotoxicity (Blöcker et al., 2001; Nagahama et al., 2002). The pronase studies suggest that solution-generated Ib oligomers, once bound to cells, remain exposed and do not insert into lipid membranes.

There are other proteases like pepsin, proteinase K, subtilisin, alpha-chymotrypsin, thermolysin, as well as the zinc-dependent C. perfringens lambda protease that activate Ibp more efficiently than trypsin. Besides Ibp, Ia also undergoes proteolysis by some of these same enzymes with an additional loss of 9-13 amino acids from the N-terminus after cleavage of leader peptide (Gibert et al., 2000). Proteolysis of Ia leads to increased cytotoxicity of Vero cells, when combined with Ib. It is still uncertain whether proteolysis of Ia affects docking efficiency to cell-bound Ib, translocation into cells, and/or enzymatic activity. Proteolysis effects upon A components from other clostridial binary toxins has not been reported to date. As the iota-family members are enteric, it is perhaps an evolutionary advantage to become activated by many different proteases from not only the host microbe, but also neighboring bacteria and eukaryotic host. Proteolytic activation, and subsequent resistance to proteolysis-based inactivation, is a common theme with clostridial toxins from various species.

Structure-function studies have been done with iota toxin, targeting Ib via deletion mutagenesis and antibody studies (Marvaud et al., 2001). Similar studies are lacking in the literature for B components from CST and CDT. Deletion of just 10 residues from the C-terminus (domain 4) effectively prevents Ib binding to Vero cells. C-terminal peptides of Ib containing more than 200 amino acids represent competitive inhibitors of iota cytotoxicity in vitro. On the other end, deletion of $27 \mathrm{~N}$-terminal residues prevents Ia docking and intoxication, yet has little effect upon Ib binding to the cell surface.

Studies with monoclonal antibodies (Mabs) against an $\mathrm{N}$ terminal epitope within residues 28-66 reveal no effect upon Ib binding or cytotoxicity (Marvaud et al., 2001). It is possible that these immunoreagents do not occupy the Ib site necessary for Ia 
docking and/or perhaps are displaced upon Ib oligomerization or docking of Ia. An obvious void in the literature involves affinity constants for A-B docking amongst clostridial binary toxins, which evidently does not occur at an appreciable rate in solution versus on a cell surface.

Two other Mabs recognize unique Ib epitopes within the Cterminus (residues 632-655), protecting against iota cytotoxicity via distinct mechanisms. One Mab prevents Ib binding to cells while the other does not; however, this latter antibody efficiently prevents Ib oligomerization on the cell surface. These latter results further demonstrate the importance of $\mathrm{Ib}$ oligomerization on iota-toxin activity, which is a common theme amongst clostridial binary toxins. Unfortunately, from an antibody probe perspective, none of the $\mathrm{N}$ - or $\mathrm{C}$-terminal binders recognize $\mathrm{Ib}$ bound to the cell surface.

Each Mab against $\mathrm{Ib}$ recognizes $\mathrm{Ibp}$ or C. spiroforme $\mathrm{Sb}$ in an ELISA and Western blot, but not B. anthracis PA (Marvaud et al., 2001). A similar effort with CDTb is obviously lacking. Surprisingly, C2II (activated form designated as C2IIa) is recognized by one of the C-terminal binding Mabs in an ELISA; however, in contrast to iota toxin this immunoreagent does not neutralize C2 cytotoxicity. C2IIa and Ib bind unique receptors via their C-terminus and share little sequence homology within the C-terminal domain (Fritz et al., 1995; Blöcker et al., 2000). Although previous efforts have targeted the N- and C-termini of Ib through different techniques, a more thorough understanding of the clostridial binary toxins could perhaps now be gleaned by focusing upon internal domains 2 and 3.

Like the iota-family toxins, the $80 \mathrm{kDa}$ (or $100 \mathrm{kDa}$ ) C2II precursor of C2 toxin is activated by trypsin into $60 \mathrm{kDa}$ (or $80 \mathrm{kDa}$ ) C2IIa (Blöcker et al., 2000). Size differences in precursor and activated C2II can vary, depending upon strain and C-terminal extension that increases toxin potency (Sterthoff et al., 2010). C2IIa, but not the C2II precursor, forms stable homoheptamers in solution (Barth et al., 2000; Kaiser et al., 2006). Electron microscopy of C2IIa oligomers on lipid bilayers reveals donut-, as well as horseshoe-, shaped heptamers with inner (20-40 $\AA$ ) and outer (110-130 §) diameters (Barth et al., 2000) further confirmed by Schleberger et al. (2006) via modeling. In similar fashion as the iota toxin, the C2II precursor binds to cells but is not activated by surface proteases and does not dock C2I (Ohishi, 1987; Ohishi and Yanagimoto, 1992).

C2IIa forms ion-permeable, cation-selective channels in artificial black lipid bilayer membranes that are blocked by complementary C2I (Schmid et al., 1994; Bachmeyer et al., 2001; Blöcker et al., 2003). A cluster of hydrophobic and hydrophilic amino acids (303-331) within C2II may play a critical role in membrane insertion, along with E399 and F428 (Blöcker et al., 2003; Lang et al., 2008). Moreover, in acidic media, C2IIa forms pores in the cytoplasmic membranes of intact cells which translocate C2I directly into the cytosol. Such experiments mimic acidified endosomes where C2IIa heptamers form transmembrane pores to translocate C2I from the endosomal lumen, across the endosomal membrane, and into the cytosol.

As described by different groups for both C. perfringens Ib and B. anthracis $\mathrm{PA}$, studies also reveal that the C-terminus of C2IIa facilitates binding to cell-surface receptor (Blöcker et al., 2000).
Antiserum specific for the C-terminus (domain 4; residues 592721), but not domains 1 (residues 1-264) or 3 (residues 490-592), blocks C2IIa binding to cells. Antiserum against domain 4 neutralizes $\mathrm{C} 2$ cytotoxicity in vitro when preincubated with C2IIa, but this is not the case after C2IIa has bound the cell surface. As described for Ib Mabs binding to Ib (Marvaud et al., 2001; Stiles et al., 2002), neutralizing epitopes on C2IIa are perhaps sterically hindered after C2IIa-cell receptor interactions. Deletion studies targeting the N-terminus of C2II precursor show that loss of residues 1181 , normally cleaved upon proteolytic activation, impacts proper folding (Blöcker et al., 2000). The sequence similarities existing between PA, C2II, and Ib are primarily localized within central domains 2 and 3. For PA, these domains participate in oligomerization, channel formation, and enzyme translocation (Benson et al., 1998; Mogridge et al., 2001; Sellman et al., 2001). Except for one study with C. botulinum C2II (Blöcker et al., 2003), very little structure-function analysis has occurred within domains 2 and 3 of $\mathrm{B}$ components from the other clostridial binary toxins.

\section{STRUCTURE AND FUNCTION OF A COMPONENTS}

Enzymatic components of iota, CDT, and C2 toxins consist of two comparable-sized domains of $\sim 200$ amino acids. The $\mathrm{N}$ terminal domain of each is enzymatically inactive and serves as a docking site for complementary B component. Residues 1-87 of C2I mediate binding to C2II heptamers and translocation into the cytosol (Barth et al., 1998a, 2002a,b). Alignment of C2I with Bacillus cereus vegetative insecticidal protein 2 (VIP2), a related ADP-ribosyltransferase, reveals relatedness within amino acids 1225 (C2I) and 60-275 (VIP2) that includes four exposed $\alpha$-helices (Han et al., 1999). Active sites are located in the C-terminus of these enzymes, harboring conserved amino acids for catalysis. Mutation of the first glutamic acid in the EXE motif of C2I prevents ADP-ribosyltransferase, but not nicotinamide adenine dinucleotide (NAD)-glycohydrolase, activity while the second glutamic acid affects both (Barth et al., 1998b; Sakurai et al., 2003). An STS triad is also commonly located near the active site and promotes binding to NAD. These residues are conserved amongst various ADP-ribosyltransferases from prokaryotes and eukaryotes (Carroll and Collier, 1984; Jung et al., 1993; van Damme et al., 1996; Han et al., 1999; Sakurai et al., 2003).

Mutagenesis of Ia within the NAD binding cavity reveals that $\mathrm{Y}_{246}$ and $\mathrm{N}_{255}$ are important for ADP-ribosyltransferase, but not NAD-glycohydrolase, activity while $\mathrm{Y}_{251}$ is involved in both (Sakurai et al., 2003). Enzymatic activity is inhibited by removing divalent cations associated with actin, but low temperature $\left(0^{\circ} \mathrm{C}\right)$ remarkably decreases activity by only $50 \%$ versus that at $37^{\circ} \mathrm{C}$ (Just et al., 1990).

Crystallography studies with components of different clostridial binary toxins have been reported by various groups. Tsuge et al. $(2003,2008)$ revealed Ia interactions with actin at $2.8 \AA$ resolution (Figure 2). Similar efforts by Sundriyal et al. (2009) show CDTa (1.85-2.25 $\AA$ resolution) at different $\mathrm{pH}(4.0,8.5,9.0)$ and complexed with NAD. C2I has also been resolved at $1.75 \AA$, and like CDTa, there are few conformational changes that occur with varying $\mathrm{pH}$ (Schleberger et al., 2006). This latter point is particularly pertinent since an acidic environment (endosome or extracellular fluid), with C2II-mediated channels, promotes C2I 


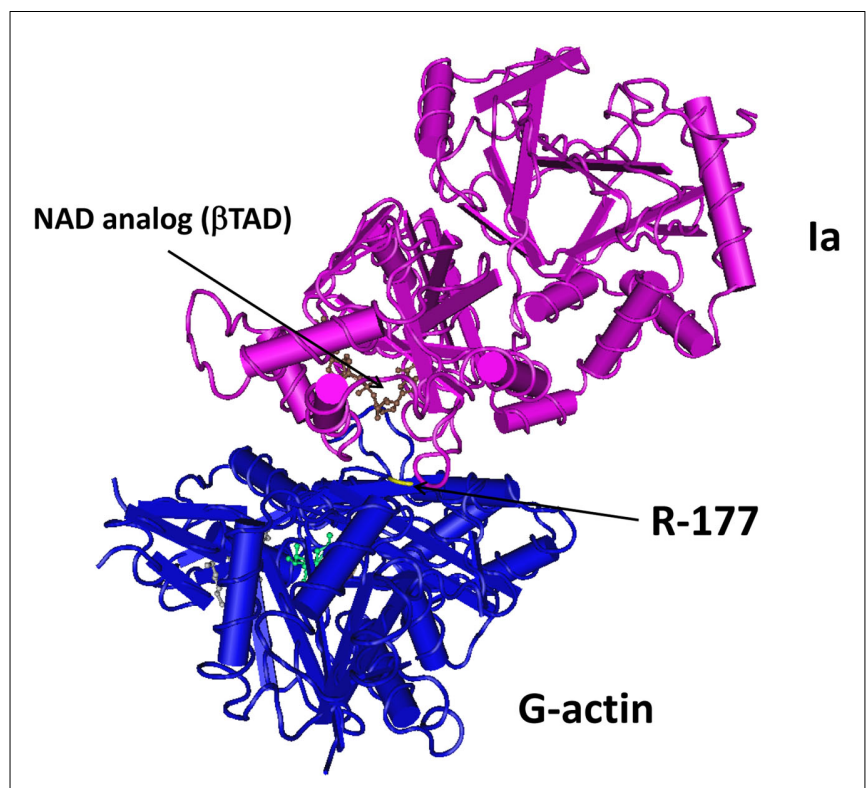

FIGURE 2 | Crystal structure of la with G-actin. Figure was generated using Entrez's Molecular Modeling Database (Wang et al., 2007), based upon co-crystal structure from Tsuge et al. (2008) at $2.8 \AA$ resolution.

translocation into the cytosol. Sequence identity of C2I with Ia (or CDTa) is only 40\%. A similar duplicate domain structure exists for the related B. cereus VIP2 (Han et al., 1999). Like the clostridial binary toxins, VIP2 is transported into cells via a separate $\mathrm{B}$ component (VIP1) that forms oligomers and channels in lipid membranes (Leuber et al., 2006). Relative to the iota and C2 family toxins, less is known about VIPs produced by Bacillus species.

\section{CELLULAR UPTAKE OF CLOSTRIDIAL BINARY TOXINS}

To come within range of any intracellular substrate, and like other bacterial protein toxins, the clostridial and bacillus binary toxins must first bind to the exterior of a targeted cell (Figure 3). This is followed by internalization of the toxin complex and translocation of A component from acidified endosome into the host-cell's cytosol. These individual steps during cellular uptake are mediated by the multifunctional B components of binary toxins (Barth et al., 2004). Serine-type proteases activate B monomers that then form homoheptamers (most commonly reported arrangement) on the cell surface or in solution prior to cell contact. Binding of B components from clostridial binary toxins involves lipid rafts (Hale et al., 2004; Nagahama et al., 2004, 2009), with the B oligomer - receptor complex acting as a docking platform for A component(s). The receptors for Ib and C2IIa are distinct proteins, in which carbohydrates play an important role in binding of C2IIa but not Ib (Eckhardt et al., 2000; Stiles et al., 2000). In contrast, the cell-surface receptors for B. anthracis PA have been definitively identified as tumor endothelium marker (TEM) 8 (Bradley et al., 2001) and human capillary morphogenesis gene (CMG) 2 (Scobie et al., 2003). Lipid rafts also facilitate PA clustering and endocytosis (Abrami et al., 2003).
To further understand the binding and oligomerization of clostridial binary toxins on cells, the potential role played by lipid rafts has been explored by different research groups. Lipid rafts are dynamic, cholesterol-rich, detergent-insoluble (at $4^{\circ} \mathrm{C}$ ) regions on cell membranes that popularly serve as portals for invasive bacteria, viruses, and toxins (Vieira et al., 2010). It has been shown that C. perfringens Ib localizes into these membrane microdomains on Vero cells (Hale et al., 2004; Nagahama et al., 2004). The Ibp molecule, which binds to cells but does not promote iota toxicity, is not associated with lipid rafts on the cell surface. This finding suggests that the receptor for iota toxin exists outside of lipid rafts, but is perhaps "dragged" into these microdomains after binding to Ib. Protein composition of Ib-containing lipid rafts from Vero cells has been determined by proteomics (Blonder et al., 2005). Recent work by Schwan et al. (2011) suggests that lipid rafts also play a role in CDT intoxication, which includes unique microtubule-based extensions from intoxicated cells that promote $C$. difficile adherence. This same group (Papatheodorou et al., 2011) has recently revealed a rather obscure protein, lipolysis-stimulated lipoprotein receptor (LSR), as a receptor for CDTb and Ib. LSR is a type I transmembrane protein involved in uptake of lipoproteins, but has never been described as a receptor for any bacterial toxin. Such a finding excitingly paves the way for further understanding the uptake mechanisms of the iota-family toxins, which could lead to unique toxin-targeting therapies.

In addition to $\mathrm{Ib}$, receptor-binding studies have also been reported for precursor and proteolytically activated forms of C2II (Ohishi and Miyake, 1985). C2IIa has unique hemagglutinating properties competitively inhibited by various carbohydrates such as $N$-acetylgalactosamine, $N$-acetylglucosamine, L-fucose, galactose, or mannose (Sugii and Kozaki, 1990). Trypsin or pronase treatment of human erythrocytes prevents C2II-induced hemagglutination, suggesting a glycoprotein of unknown identity. Furthermore, Fritz et al. (1995) revealed that chemically mutagenized CHO cells do not bind C2IIa. These cells are devoid of $\mathrm{N}$-acetylglucosaminyltransferase I which facilitates formation of asparagine-linked complex and hybrid carbohydrates (Eckhardt et al., 2000). These cells are still susceptible to iota toxin; therefore, demonstrating that C2IIa and Ib recognize different receptors. C2, like iota and the B. anthracis binary toxins, uses lipid rafts for binding and entry into cells (Nagahama et al., 2009). C2 toxin effectively intoxicates all tested vertebrate cells (Ohishi et al., 1984; Sugii and Kozaki, 1990; Eckhardt et al., 2000), but the receptor for Ib is not as ubiquitous (Stiles et al., 2000).

The Ib receptor is resistant to various proteases, but not pronase. Rather extensive pretreatment of cells with lectins or glycosidases does not affect Ib binding, thus suggesting that carbohydrates play no role (Stiles et al., 2000). Experiments with polarized CaCo-2 (human colon) cells show that $\mathrm{Ib}$ receptor is namely localized upon the basolateral membrane (Blöcker et al., 2001; Richard et al., 2002). Additionally, Ib crosses a CaCo-2 cell monolayer at $37^{\circ} \mathrm{C}$ (but not $4^{\circ} \mathrm{C}$ ) from the apical or basolateral surface independent of Ia (Richard et al., 2002). Ib that has traveled across a monolayer can internalize Ia on this distal surface, even when Ia is added $3 \mathrm{~h}$ after Ib.

Western blot experiments reveal that Ib rapidly binds to cells at $37^{\circ} \mathrm{C}$ and forms a large $(>200 \mathrm{kDa})$ complex within $1 \mathrm{~min}$ 


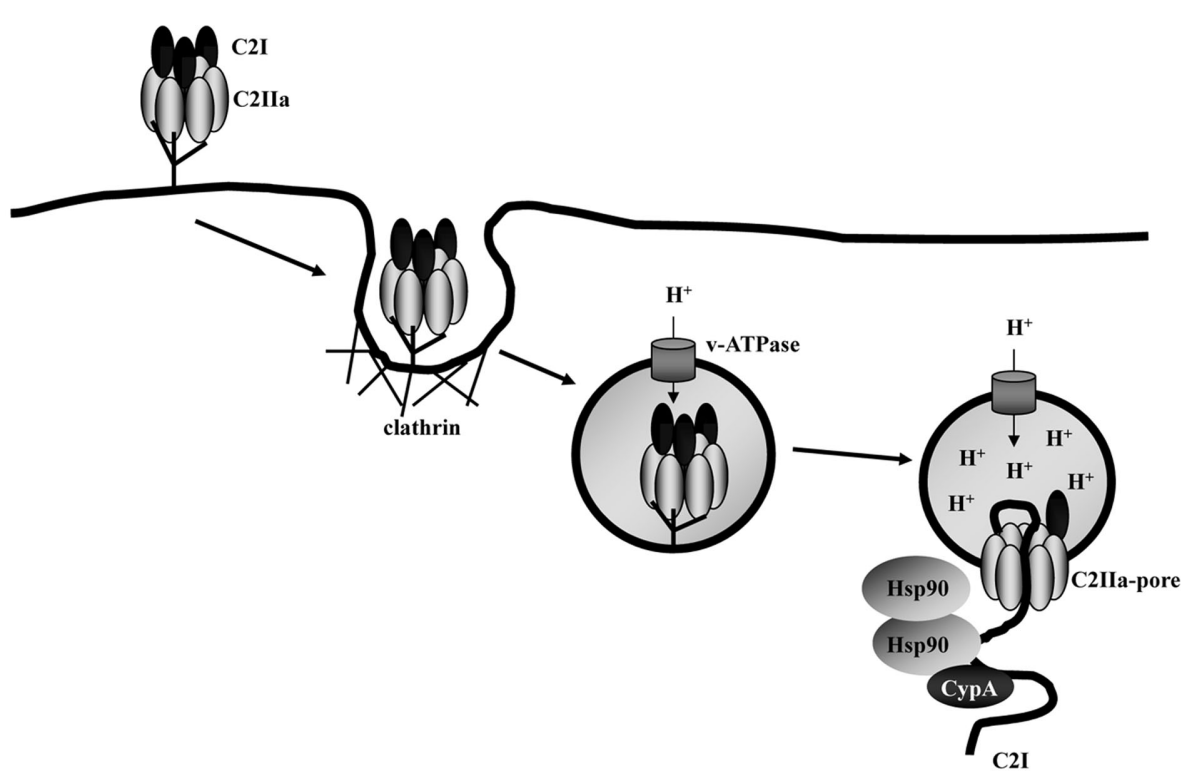

FIGURE 3 | Model for the cellular uptake of C2 toxin from

C. botulinum. The $\mathrm{C} 2 \mathrm{lla} / \mathrm{C} 21$ toxin complex binds to a receptor on the cell surface and is internalized via clathrin-dependent receptor-mediated

endocytosis. Acidic conditions in the lumen of early endosomes trigger membrane insertion and pore formation by $\mathrm{C} 2 \mathrm{lla}$. C2I translocates in an unfolded conformation through the C2lla pores across endosomal membranes into the cytosol. Hsp90 and cyclophilin A (CypA) facilitate translocation.
(Nagahama et al., 2002; Stiles et al., 2002). This complex, which does not form at $4^{\circ} \mathrm{C}$, remains for at least $6 \mathrm{~h}$ and thus promotes Ia docking opportunities that generate holotoxin. Rapid binding of Ib followed by surface-sustained availability for Ia makes sense for any clostridial binary toxin.

Beyond cell-based studies, Sakurai and Kobayashi (1995) discovered that when $\mathrm{Ib}$ is injected intradermally into guinea pigs, Ia (injected intraperitoneally) can "find" Ib and cause localized dermonecrosis. Perhaps this "homing" characteristic of Ia can be exploited in future experiments from a medicinal perspective. Similar discoveries have been reported for the $\mathrm{C} 2$ toxin in both mice and rats (Simpson, 1982).

Following receptor-mediated endocytosis of the clostridial binary toxins, which can occur via clathrin-dependent and independent mechanisms (Pust et al., 2010; Gibert et al., 2011), the A components of iota, CDT, and C2 toxins cross the endosomal membrane into the cytosol (Barth et al., 2000; Blöcker et al., 2001; Kaiser et al., 2011). This step is mediated by transmembrane pores formed by the $\mathrm{B}$ components and can be blocked by a macrolide antibiotic, bafilomycin A, which inhibits vacuolartype ATPases that acidify the endosomal lumen. This suggests that acidic conditions are crucial for translocating A components from endosomes into the cytosol. Low $\mathrm{pH}$ evidently induces conformational changes within the B complex, promoting insertion into membranes and subsequent translocation of A components through pores into the cytosol. This process is also artificially induced from the cell surface into the cytosol by simply lowering media pH (Barth et al., 2000; Blöcker et al., 2001). There are unique $\mathrm{pH}$ requirements for translocating iota and $\mathrm{C} 2$ toxins, as iota requires a lower $\mathrm{pH}(\leq 5.0)$ versus $\mathrm{C} 2(\leq 5.5)$. The biochemical reasons for this difference are not known. Conversion of $B$. anthracis $\mathrm{PA}$ heptamer from a pre-pore to pore state, when bound to $\mathrm{CMG} 2$ receptor, is also $\mathrm{pH}$ driven and controlled by the receptor (Lacy et al., 2004). Perhaps the unique receptors recognized by C2 and iota toxins play similar roles during $\mathrm{pH}$-induced translocation.

Furthermore, entry of iota toxin from the endosome into the cytosol of Vero cells differs from C2 toxin as per chloroquine, monensin, nigericin, and ammonium chloride inhibition (Gibert et al., 2007). Besides preventing endosomal acidification, chloroquine also physically blocks the C2IIa-induced pore thereby stopping C2I translocation (Schmid et al., 1994; Blöcker et al., 2003). Monensin, like nigericin, exchanges monovalent cations for protons that abolish the endosomal $\mathrm{pH}$ gradient. Because of inherent alkalinity, ammonium chloride increases $\mathrm{pH}$ within endosomes. The biological activity of iota toxin on Vero cells is not inhibited by monensin alone; however, a combination of monensin and valinomycin (a potassium ionophore) proves partially inhibitory, and there is a distinct decrement of iota-toxin activity with monensin plus bafilomycin A. Based upon these results, requirements of Ia entry from the endosome mimic those previously described for fibroblast growth factor (Wesche et al., 2006). Altogether, a $\mathrm{pH}$ gradient between the endosome and cytosol are required for translocating Ia (from early to late endosomes) and C2I (from early endosomes), but Ia also requires a membrane potential. Most likely, following translocation of A component into the cytosol, the $\mathrm{B}$ heptamers of clostridial binary toxins remain attached to the endosomal membrane and undergo lysosomal degradation (Ohishi and Yanagimoto, 1992; Richard et al., 2002). It is also possible, yet less likely, that B heptamers recycle back onto the cell-surface following release of A into the cytosol.

For $\mathrm{C} 2$ toxin it has been shown that translocation requires partial unfolding of the A component, C2I (Haug et al., 2003b). It can 
be expected that A components from the other clostridial binary toxins also unfold into a "molten globule" to translocate through B heptameric pores within the endosomal membrane. Perhaps this occurs in a ratchet-type mechanism similar to the $B$. anthracis lethal factor (LF) via an $\mathrm{N}$ - to C-terminal direction, through the $\mathrm{B}$ (PA) pore, into the cytosol (Zhang et al., 2004; Krantz et al., 2006).

Recent studies with the C2, CDT, and iota toxins reveal that $\mathrm{pH}$-dependent membrane translocation and/or refolding of the A components is facilitated by host-cell factors including the chaperone heat-shock protein 90 (Hsp90), and cyclophilin A, a peptidyl-prolyl cis/trans-isomerase (PPIase) (Haug et al., 2003a, 2004; Kaiser et al., 2009, 2011). PPIases are helper enzymes that catalyze slow protein-folding reactions (Fischer et al., 1989; Schmid, 1993). Treatment of cultured cells with specific pharmacological inhibitors of Hsp90 (geldanamycin and radicicol) or cyclophilin A (cyclosporine A) significantly delay the C2-, CDT-, and iotainduced rounding of cells. Moreover, these inhibitors prevent uptake of A components into the cytosol but do not influence other aspects of toxin uptake or enzyme activity. Inhibition of the chaperone and PPIase activities of Hsp90 and cyclophilin A respectively prevent translocation of A components into the cytosol, thus trapping them in the endosomes. The A components directly interact with purified $\mathrm{Hsp} 90$ and cyclophilin A proteins in vitro (Kaiser et al., 2009, 2011). Although the data support a common Hsp90/cyclophilin A-dependent translocation for clostridial binary toxins, the precise molecular mechanisms underlying the interaction between these host-cell factors and A components is not known and requires further investigation. Interestingly, Hsp90 is a conserved ATPase present in all eukaryotic cells and often complexed with other proteins, including PPIases (Wandinger et al., 2008). In conjunction with other heat-shock proteins, Hsp90 regulates trafficking of "client" proteins into the cytosol and assists various cell functions that include signaling (Pratt and Toft, 2003; Zuehlke and Johnson, 2010). The translocation process used by clostridial binary toxins is akin to that exploited by another ADPribosyltransferase from Corynebacterium diphtheriae, diphtheria toxin, involving a cytosolic complex of Hsp90 and thioredoxin reductase (Ratts et al., 2003). The latter might cleave the disulfide bond between A and B chains of diphtheria toxin, in which such reduction-based activation exists for other single-chain proteins like C. tetani tetanus toxin and C. botulinum neurotoxin A (Kistner and Habermann, 1992). However, such a cystine bond does not exist between $\mathrm{AB}$ components for clostridial and bacillus binary toxins.

In contrast to the clostridial binary toxins, cytosolic entry of B. anthracis lethal toxin is not affected by Hsp90 inhibitors (Haug et al., 2003a; Zornetta et al., 2010; Dmochewitz et al., 2011). This latter result further suggests differences in translocating clostridial and bacillus binary toxins. Moreover, Hsp90 might be generally selective for bacterial ADP-ribosyltransferases like the cholera toxin of Vibrio cholerae (Taylor et al., 2010), which is structurally distinct from the binary toxins described in this current review.

New knowledge about the molecular mechanisms underlying cellular uptake of binary clostridial toxins can provide useful therapeutic targets against these toxins. For example, targeting of CDT could perhaps diminish some of the enteric ill-effects of epidemic (CDT-producing) strains of $C$. difficile. Examples of novel therapeutics might include derivatives of chloroquine (Bachmeyer et al., 2001) or methyl- $\beta$-cyclodextrin (Nestorovich et al., 2011), which interfere with pore formation by B components and subsequent translocation of A components. Another possibility is the targeted pharmacological inhibition of individual host-cell factors that translocate A components, such as cyclophilin A (Barth, 2011).

A more comprehensive understanding of how clostridial binary toxins enter cells can also aid their potential use as medicinal shuttles. This latter aspect is particularly interesting since fragments of the C2 (Barth et al., 1998a, 2002b; Pust et al., 2007; Fahrer et al., 2010a,b) and iota (Marvaud et al., 2002) toxins have been successfully employed as "Molecular Trojan Horses" to deliver foreign proteins (e.g., enzymes) into the cytosol of various mammalian cell types without causing damage during entry. Because this approach enables targeted manipulation of living cells, recombinant fusion toxins do not only represent valuable tools for cell biology and experimental pharmacology, but also potentially attractive therapeutics (Barth and Stiles, 2008).

\section{ADP-RIBOSYLATION OF ACTIN. .. A PATHOGEN'S SURGICAL STRIKE UPON THE CYTOSKELETON}

Mono-ADP-ribosylation of host proteins is a common mechanism employed by diverse, pathogenic bacteria via the actions of protein toxins (Masignani et al., 2006). All of these toxins use eukaryotic-provided NAD, a ubiquitous molecule necessary for energy metabolism, as a source of ADP-ribose to alter the function of critical eukaryotic proteins necessary for life.

There are four groups of ADP-ribosylating toxins based upon their intracellular targets: (1) elongation factor two (EF2) modified by $C$. diphtheriae diphtheria toxin and Pseudomonas aeruginosa exotoxin A via an $\mathrm{N}$ - and C-terminal active site, respectively; (2) heterotrimeric G-proteins targeted by Bordetella pertussis pertussis toxin, Escherichia coli heat labile enterotoxin, and $V$. cholerae cholera toxin by way of N-terminal active sites; (3) Rho and Ras GTPases modified by $C$. botulinum C3 exoenzyme and $P$. aeruginosa exoenzyme $\mathrm{S}$ through C-terminal active sites; and (4) G-actin (Holbourn et al., 2006; Masignani et al., 2006). All actin-modifying toxins have a C-terminal active site and are designated as type IV ADP-ribosyltransferases. Although sequence homologies may be low between different ADP-ribosyl transferases (i.e., prokaryotic and eukaryotic), topography of the enzymatic cleft and catalytic residues remains quite conserved (Tsuge et al., 2008).

Pathogen disruption of the eukaryotic cytoskeleton through actin can alter many vital processes, including: (1) vesicle trafficking; (2) phagocytosis; (3) migration; (4) epithelial barrier formation and binding to extracellular matrix; as well as (5) signaling (Aktories et al., 2011). Ultimately, these cumulative events induce cell death with subsequent release of valuable, intracellular nutrients for the pathogen and other microbes within that microenvironment. Furthermore, bacterial toxins that modify actin have become invaluable tools for studying the cytoskeleton and numerous cell processes.

Actin is a conserved protein ( $\sim 42 \mathrm{kDa}$ in monomeric $\mathrm{G}$ form) found throughout nature, playing a pivotal role in filament (F-actin) formation essential for cytoskeleton development and cellular processes (Wertman and Drubin, 1992; Aktories et al., 
2011). Mono-ADP-ribosylation of G-actin inhibits monomer assembly into F-actin strands (Aktories et al., 1986, 2011), via steric hindrance of hydrophobic loop interactions between G-actin molecules (Figure 4). Ultimately modified G-actin does not bind F-actin strands, decreasing concentrations of the latter, while concomitantly increasing the G-actin pool inside a cell (Aktories et al., 1989). In addition to the actin-gelsolin complex, both the iota and C2 toxins modify G-actin complexed with ATPase that results in increased exchange, but decreased hydrolysis, of ATP (Geipel et al., 1989). F-actin does not represent a direct target for any clostridial binary toxins.

There are six actin isoforms in birds and mammals, depending upon tissue type, and include: $\alpha$-skeletal; $\alpha$-cardiac; $\alpha$ and $\gamma$ smooth muscle; as well as $\beta$ and $\gamma$ cytoplasmic (Perrin and Ervasti, 2010; Aktories et al., 2011). Interestingly, bacteria also contain a cytoskeletal matrix consisting of actin homologs (MamK, MreB, ParM, etc.) that vary between species (Cabeen and Jacobs-Wagner, 2010). Like eukaryotes, the cytoskeleton of a bacterium plays major life-sustaining functions that include division, shape, protein localization, and DNA segregation. The targeting of prokaryotic actin, similar to the iota and C2 toxins that modify eukaryotic actin, could perhaps lead to novel anti-infectives (Vollmer, 2006). We are unaware of any bacterial toxin that modifies bacterial homologs of actin. Along these lines, an indole compound inhibits growth of efflux-deficient $P$. aeruginosa by binding to the ATP-binding site on MreB (Robertson et al., 2007).

The clostridial binary toxins form two obvious groups based upon actin substrates. The $C$. botulinum $\mathrm{C} 2$ toxin only modifies $R_{177}$ of $\beta / \gamma$-non-muscle, as well as $\gamma$-smooth muscle, $G$-actin (Aktories et al., 1986; Ohishi and Tsuyama, 1986; Vandekerckhove et al., 1988). In contrast, the iota-toxin family is less discriminating and modifies all known G-actin isoforms (Mauss et al., 1990). The enzymatic CDTa, Ia, and Sa components each possess a LKDKE sequence, important for binding to G-actin, within the N-terminus (Popoff, 2000). However, the C2I molecule has a unique actin-binding sequence (LKTKE) and location that might help explain distinct substrate specificity.

Uematsu et al. (2007) have shown that actin disassembly by C2 toxin induces microtubule assembly and polarization of human leukemic cell lines. More recent studies by Schwan et al. (2009,

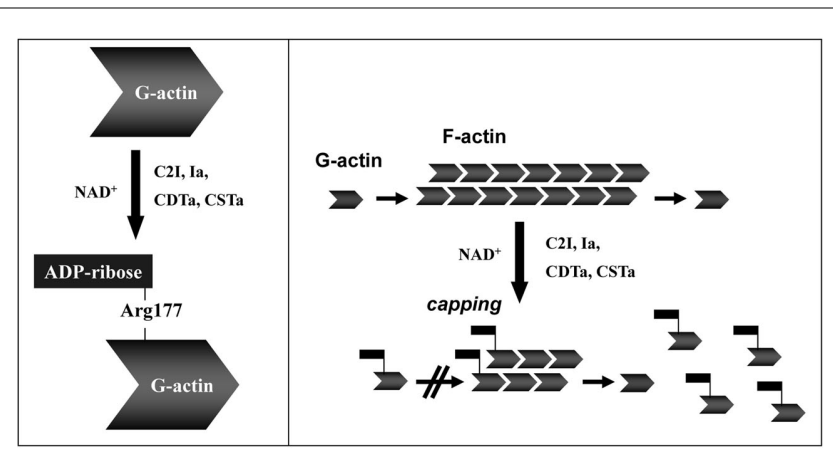

FIGURE 4 | Toxin-catalyzed mono-ADP-ribosylation of G-actin results in depolymerization of actin filaments (F-actin). Details are given in the text.
2011) reveal that treatment of gastric epithelial cells with CDT, iota, or $\mathrm{C} 2$ toxin induces microtubule protrusions from the membrane that promote adherence and colonization of $C$. difficile to the colonic mucosa. These protrusions are most likely dependent on cholesterol- and sphingolipid-rich microdomains of the cytoplasmic membrane (Schwan et al., 2011). This concept introduces a novel twist to pathogen-cell interactions, elicited by clostridial binary toxins.

Furthermore, ADP-ribosylation of actin by $\mathrm{C} 2$ toxin arrests cell cycling at the G2/M boundary (Barth et al., 1999). Treatment with either the $\mathrm{C} 2$ or iota toxins results in delayed caspase-dependent death $\sim 20 \mathrm{~h}$ after toxin application (Heine et al., 2008; Hilger et al., 2009). It is clear that toxins, like those produced by clostridia and which specifically modify actin, have become invaluable tools for studying cell biology and experimental pharmacology. There is much more to be learned from the ways these toxins work on cells.

\section{PEERING INTO THE FUTURE VIA A PORTAL OF THE PAST}

Discovery of C. perfringens iota toxin in 1940 by Bosworth was the first for any clostridial binary toxin. It was not until 1956 that the multi-component structure of $B$. anthracis toxins was initially reported, thus representing the first binary description for any bacterial toxin (Smith, 2002). The passing of three more decades eventually revealed the multi-component nature of various clostridial binary toxins described in this review. Many different laboratories led to these discoveries, with different toxins, from different clostridia.

The B heptamers from clostridial binary toxins shuttle one type of enzyme, a mono-ADP-ribosyltransferase specific for Gactin, into cells. This paradigm diverges with the B. anthracis PA, which transports lethal (LF) and edema (EF) factors possessing different enzymatic properties. Additionally, recent findings by Kronhardt et al. (2011) show that PA can also bind and subsequently transport C. botulinum C2I into cells. The efficiency of C2I transport by PA was at least 50-fold less than C2IIa. Furthermore, EF and LF bind to C2IIa oligomers in lipid bilayers but are not transported into cells. Within the iota family, enzyme is transported by heterologous B components from other clostridial species. To date, the C. botulinum $\mathrm{C} 2$ toxin is still distinct amongst the clostridial binary toxins in that C2IIa exclusively transports C2I. An ability of these B components to transport another protein into a cell makes them natural shuttles that can perhaps, with further study, transport medicinal molecules into cells. Crossing of a medicinal molecule through a cell membrane into the cytosol can be a daunting challenge, but the aforementioned Clostridium and Bacillus binary toxins have naturally solved this problem for rather large (i.e., protein) cargo. An important discovery for better understanding the mode of action of any bacterial toxin involves specific receptor identification. Very recent work by Papatheodorou et al. (2011), in which LSR serves as a receptor for Ib and CDTb, opens up an exciting realm for future research with the iota-family toxins.

It is our opinion that genetic analysis of other species (genera perhaps?) will yield more binary toxin-like producers, as evidenced by a PCR-based study showing C. novyi type A strains containing the C. botulinum C2I and/or C2II genes (Heffron and 
Poxton, 2007). Additionally, some strains of B. cereus associated with lethal pneumonia in humans possess the anthrax toxin genes (Hoffmaster et al., 2004). Furthermore, one of these isolates produce a novel ADP-ribosyltransferase called certhrax which shares $34 \%$ identity with the catalytic region of CDTa (Hoffmaster et al., 2006; Fieldhouse et al., 2010). Certhrax also possesses 31\% identity with LF, but lacks protease activity. Such discoveries reveal a dispersed genetic template for binary toxins that is, to date, more prevalent in clostridia. Evidently binary toxin "successes" of the

\section{REFERENCES}

Abrami, L., Liu, S., Cosson, P., Leppla, S. H., and van der Goot, F. G. (2003). Anthrax toxin triggers endocytosis of its receptor via a lipid raft-mediated clathrindependent process. J. Cell Biol. 160, 321-328.

Agnoletti, F., Ferro, T., Guolo, A., Marcon, B., Cocchi, M., Drigo, I., Mazzolini, E., and Bano, L. (2009). A survey of Clostridium spiroforme antimicrobial susceptibility in rabbit breeding. Vet. Microbiol. 136, 188-191.

Aktories, K., Bärmann, M., Ohishi, I., Tsuyama, S., Jakobs, K. H., and Habermann, E. (1986). Botulinum C2 toxin ADP-ribosylates actin. Nature 322, 390-392.

Aktories, K., Lang, A. E., Schwan, C., and Mannherz, H. G. (2011). Actin as target for modification by bacterial protein toxins. FEBS J. 278, 4526-4543.

Aktories, K., Reuner, K.-H., Presek, P., and Barmann, M. (1989). Botulinum $\mathrm{C} 2$ toxin treatment increases the G-actin pool in intact chicken cells: a model for the cytopathic action of actin-ADP-ribosylating toxins. Toxicon 27, 989-993.

Avbersek, J., Cotman, M., and Ocepek, M. (2011). Detection of Clostridium difficile in animals: comparison of real-time PCR assays with the culture method. J. Med. Microbiol. 60, 1119-1125.

Babudieri, S., Borriello, S. P., Pantosti, A., Luzzi, I., Testore, G. P., and Panichi, G. (1986). Diarrhoea associated with toxigenic Clostridium spiroforme. J. Infect. 12, 278-279.

Bacci, S., Molbak, K., Kjeldsen, M. K., and Olsen, K. E. (2011). Binary toxin and death after Clostridium difficile infection. Emerg. Infect. Dis. 17, 976-982.

Bachmeyer, C., Benz, R., Barth, H., Aktories, K., Gibert, M., and Popoff, M. (2001). Interaction of Clostridium botulinum C2-toxin with lipid bilayer membranes and Vero cells: inhibition of channel function by chloroquine and related compounds in vitro and intoxication in vivo. FASEB J. 15, 1658-1660.

Barbut, F., Gariazzo, B., Bonne, L., Lalande, V., Burghoffer, B., Luiuz, R., and Petit, J. C. (2007). Clinical feature of Clostridium difficileassociated infections and molecular characterization of strains: results of a retrospective study, 2000-2004. Infect. Control Hosp. Epidemiol. 28, 131-139.

Barbut, F., Monot, M., Rousseau, A., Cavelot, S., Simon, T., Burghoffer, B., Lalande, V., Tankovic, J., Petit, J. C., Dupuy, B., and Eckert, C. (2011). Rapid diagnosis of Clostridium difficile infection by multiplex real-time PCR. Eur. J. Clin. Microbiol. Infect. Dis. 30, 1279-1285.

Barth, H. (2011). Exploring the role of host cell chaperones/PPIases during cellular up-take of bacterial ADP-ribosylating toxins as basis for novel pharmacological strategies to protect mammalian cells against these virulence factors. Naunyn Schmiedebergs Arch. Pharmacol. 383, 237-245.

Barth, H., Aktories, K., Popoff, M. R., and Stiles, B. G. (2004). Binary bacterial toxins: biochemistry, biology, and applications of common Clostridium and Bacillus proteins. Microbiol. Mol. Biol. Rev. 68, 373-402.

Barth, H., Blöcker, D., and Aktories, K. (2002a). The uptake machinery of clostridial actin ADP-ribosylating toxins - a cell delivery system for fusion proteins and polypeptide drugs. Naunyn Schmiedebergs Arch. Pharmacol. 366, 501-512.

Barth, H., Roebling, R., Fritz, M., and Aktories, K. (2002b). The binary Clostridium botulinum C2 toxin as a protein delivery system: identification of the minimal protein region necessary for interaction of toxin components. J. Biol. Chem. 277, 5074-5081.

Barth, H., Blöcker, D., Behlke, J., Bergsma-Schutter, W., Brisson, A., Benz, R., and Aktories, K. (2000). Cellular uptake of Clostridium botulinum C2 toxin requires oligomerization and

past, and those today, promote further success of various bacterial pathogens into the future.

\section{ACKNOWLEDGMENTS}

Bradley G. Stiles appreciates the computer support and overall constructive environment throughout Wilson College for communicating science. Work of the Holger Barth laboratory included in this review was funded by the Deutsche Forschungsgemeinschaft (DFG) and the Faculty of Medicine, Ulm.

acidification. J. Biol. Chem. 275, 18704-18711.

Barth, H., Hofmann, F., Olenik, C., Just, I., and Aktories, K. (1998a). The Nterminal part of the enzyme component (C2I) of the binary Clostridium botulinum $\mathrm{C} 2$ toxin interacts with the binding component C2II and functions as a carrier system for a Rho ADP-ribosylating C3like fusion toxin. Infect. Immun. 66, 1364-1369.

Barth, H., Preiss, J. C., Hofmann, F. and Aktories, K. (1998b). Characterization of the catalytic site of the ADP-ribosyltransferase Clostridium botulinum $\mathrm{C} 2$ toxin by sitedirected mutagenesis. J. Biol. Chem. 273, 29506-29511.

Barth, H., Klingler, M., Aktories, K., and Kinzel, V. (1999). Clostridium botulinum C2 toxin delays entry into mitosis and activation of $\mathrm{p} 34 \mathrm{cdc} 2$ kinase and cdc25-C phosphatase in $\mathrm{HeLa}$ cells. Infect. Immun. 67 5083-5090.

Barth, H., and Stiles, B. G. (2008). Binary actin-ADP-ribosylating toxins and their use as Molecular Trojan Horses for drug delivery into eukaryotic cells. Curr. Med. Chem. 15, 459-469.

Benson, E. L., Huynh, P. D., Finkelstein, A., and Collier, R. J. (1998). Identification of residues lining the anthrax protective antigen channel. Biochemistry 37, 3941-3948.

Billington, S. J., Wieckowski, E. U., Sarker, M. R., Bueschel, D., Songer, J. G., and McClane, B. A. (1998). Clostridium perfringens type $\mathrm{E}$ animal enteritis isolates with highly conserved, silent enterotoxin gene sequences. Infect. Immun. 66 4531-4536.

Blöcker, D., Bachmeyer, C., Benz, R., Aktories, K., and Barth, H. (2003). Channel formation by the binding component of Clostridium botulinum C2 toxin: glutamate 307 of C2II affects channel properties in vitro and $\mathrm{pH}$-dependent $\mathrm{C} 2 \mathrm{I}$ translocation in vivo. Biochemistry 42, 5368-5377.

Blöcker, D., Barth, H., Maier, E., Benz, R., Barbieri, J. T., and Aktories,
K. (2000). The C-terminus of component C2II of Clostridium botulinum $\mathrm{C} 2$ toxin is essential for receptor binding. Infect. Immun. 68, 4566-4573.

Blöcker, D., Behlke, J., Aktories, K., and Barth, H. (2001). Cellular uptake of the binary Clostridium perfringens iota-toxin. Infect. Immun. 69, 2980-2987.

Blonder, J., Hale, M. L., Chan, K. C., Yu, L. R., Lucas, D. A., Conrads, T. P., Zhou, M., Popoff, M. R., Issaq, H. J., Stiles, B. G., and Veenstra, T. D. (2005). Quantitative profiling of the detergent-resistant membrane proteome of iota-b toxin induced Vero cells. J. Proteome Res. 4, 523-531.

Blossom, D. B., and McDonald, L. C. (2007). The challenges posed by reemerging Clostridium diffcile infection. Clin. Infect. Dis. 45, 222-227.

Borriello, S., and Carman, R. (1983). Association of iota-like toxin and Clostridium spiroforme with both spontaneous and antibioticassociated diarrhea and colitis in rabbits. J. Clin. Microbiol. 17, 414-418.

Bosworth, T. (1940). On a new type of toxin produced by Clostridium welchii. J. Comp. Path. 53, 245-255.

Bradley, K. A., Mogridge, J., Mourez, M., Collier, R. J., and Young, J. A. (2001) Identification of the cellular receptor for anthrax toxin. Nature 414, 225-229.

Cabeen, M. T., and Jacobs-Wagner, C. (2010). The bacterial cytoskeleton. Annu. Rev. Genet. 44, 365-392.

Carman, R. J., and Evans, R. H. (1984). Experimental and spontaneous clostridial enteropathies of laboratory and free living lagomorphs. Lab. Anim. Sci. 34, 443-452.

Carman, R. J., Stevens, A. L., Lyerly, M. W., Hiltonsmith, M. F., Stiles, B. G., and Wilkins, T. D. (2011). Clostridium difficile binary toxin (CDT) and diarrhea. Anaerobe 17, 161-165.

Carroll, K. C., and Bartlett, J. G. (2011). Biology of Clostridium difficile: implications for epidemiology and diagnosis. Annu. Rev. Microbiol. 65, 501-521. 
Carroll, S. F., and Collier, R. J. (1984). NAD binding site of diphtheria toxin: identification of a residue within the nicotinamide subsite by photochemical modification with NAD. Proc. Natl. Acad. Sci. U.S.A. 81, 3307-3311.

Devriese, P. P. (1999). On the discovery of Clostridium botulinum. J. Hist. Neurosci. 8, 43-50.

Dmochewitz, L., Lillich, M., Kaiser, E., Jennings, L. D., Lang, A. E., Buchner, J., Fischer, G., Aktories, K., Collier, R. J., and Barth, H. (2011). Role of CypA and Hsp90 in membrane translocation mediated by anthrax protective antigen. Cell. Microbiol. 13, 359-373.

Drigo, I., Bacchin, C., Cocchi, M., Bano, L., and Agnoletti, F. (2008). Development of PCR protocols for specific identification of Clostridium spiroforme and detection of sas and sbs genes. Vet. Microbiol. 131, 414-418.

Dürre, P. (2005). Handbook on Clostridia. Boca Raton: CRC Press.

Eckhardt, M., Barth, H., Blöcker, D., and Aktories, K. (2000). Binding of Clostridium botulinum C2 toxin to asparagine-linked complex and hybrid carbohydrates. J. Biol. Chem. 275, 2328-2334.

Fach, P., Fenicia, L., Knutsson, R., Wielinga, P. R., Anniba, R., Delibato, E., Auricchio, B., Woudstra, C., Agren, J., Segerman, B., de Medici, D., and van Rotterdam, B. J. (2011). An innovative molecular detection tool for tracking and tracing Clostridium botulinum types A, $\mathrm{B}, \mathrm{E}, \mathrm{F}$ and other botulinum neurotoxin producing clostridia based on the GeneDisc cycler. Int. J. Food Microbiol. 145, S145-S151.

Fahrer, J., Plunien, R., Binder, U., Seliger, H., and Barth, H. (2010a). Genetically engineered Clostridium botulinum C2 toxin as a carrier system to deliver biomolecules into mammalian cells. Bioconjug. Chem. 21, 130-139.

Fahrer, J., Rieger, J., van Zandbergen, G., and Barth, H. (2010b). Genetic engineering, expression and characterization of recombinant streptavidin-fusion toxins as novel transfection systems for macrophages/monocytes. Biol. Chem. 391, 1315-1325.

Felsenstein, J. (1985). Confidence limits on phylogenies: an approach using the bootstrap. Evolution 39, 783-791.

Fieldhouse, R. J., Turgeon, Z., White, D., and Merrill, R. (2010). Cholera- and anthrax-like toxins are among several new ADP-ribosyltransferases.
PLoS Comput. Biol. 6, e1001029. doi:10.1371/journal.pcbi.1001029

Fischer, G., Wittman-Liebold, B., Lang, K., Kiefhaber, T., and Schmid, F. X. (1989). Cyclophilin and peptidylprolyl cis-trans isomerase are probably identical proteins. Nature 337 , 476-478.

Fritz, G., Schroeder, P., and Aktories, K. (1995). Isolation and characterization of a Clostridium botulinum C2 toxin-resistant cell line: evidence for possible involvement of the cellular C2II receptor in growth regulation. Infect. Immun. 63, 2334-2340.

Fujii, N., Kubota, T., Shirakawa, S., Kimura, K., Ohishi, I., Moriishi, K., Isogai, E., and Isogai, H. (1996). Characterization of component-I gene of botulinum $\mathrm{C} 2$ toxin and PCR detection of its gene in clostridial species. Biochem. Biophys. Res. Commun. 220, 353-359.

Geipel, U., Just, I., Schering, B., Haas, D., and Aktories, K. (1989). ADP-ribosylation of actin causes increase in the rate of ATP exchange and inhibition of ATP hydrolysis. Eur. J. Biochem. 179, 229-232.

Geric, B., Carman, R. J., Rupnik, M., Genheimer, C. W., Sambol, S. P., Lyerly, D. M., Gerding, D. N., and Johnson, S. (2006). Binary toxinproducing, large clostridial toxinnegative Clostridium difficile strains are enterotoxic but do not cause disease in hamsters. J. Infect. Dis. 193, 1143-1150.

Geric, B., Johnson, S., Gerding, D. D., Grabnar, M., and Rupnik, M. (2003). Frequency of binary toxin genes among Clostridium difficile strains that do not produce large clostridial toxins. J. Clin. Microbiol. 41, 5227-5232.

Gibert, M., Marvaud, J. C., Periera, Y., Hale, M. L., Stiles, B. G., Boquet, P., Lamaze, C., and Popoff, M. R. (2007). Differential requirement for the translocation of clostridial binary toxins: iota toxin requires a membrane potential gradient. FEBS Lett. 581, 1287-1296.

Gibert, M., Monier, M.-N., Ruez, R., Hale, M. L., Stiles, B. G., Benmerah, A., Johannes, L., Lamaze, C., and Popoff, M. R. (2011). Endocytosis and toxicity of clostridial binary toxins depend on a clathrinindependent pathway regulated by Rho-GDI. Cell. Microbiol. 13, 154-170.

Gibert, M., Perelle, S., Daube, G., and Popoff, M. R. (1997). Clostridium spiroforme toxin genes are related to $C$. perfringens iota toxin genes but have a different genomic localization. Syst. Appl. Microbiol. 20, 337-347.

Gibert, M., Petit, L., Raffestin, S., Okabe, A., and Popoff, M. R. (2000). Clostridium perfringens iota-toxin requires activation of both binding and enzymatic components for cytopathic activity. Infect. Immun. 68, 3848-3853.

Goldenberg, S. D., and French, G. L. (2011). Lack of association of tcdC type and binary toxin status with disease severity and outcome in toxigenic Clostridium difficile. J. Infect. $62,355-362$.

Gould, L. H., and Limbago, B. (2010). Clostridium difficile in food and domestic animals: a new foodborne pathogen? Clin. Infect. Dis. 51, 577-582.

Gülke, I., Pfeifer, G., Liese, J., Fritz, M., Hofmann, F., Aktories, K., and Barth, H. (2001). Characterization of the enzymatic component of the ADPribosyltransferase toxin CDTa from Clostridium difficile. Infect. Immun. 69, 6004-6011.

Hale, M. L., Marvaud, J. C., Popoff, M. R., and Stiles, B. G. (2004). Detergent-resistant membrane microdomains facilitate Ib oligomer formation and biological activity of Clostridium perfringens iota-toxin. Infect. Immun. 72, 2186-2193.

Hall, I. C., and O'Toole, E. (1935). Intestinal flora in new-born infants with a description of a new pathogenic anaerobe, Bacillus difficilis. Am. J. Dis. Child. 49, 390-402.

Han, S., Craig, J. A., Putnam, C. D., Carozzi, N. B., and Tainer, J. A. (1999). Evolution and mechanism from structures of an ADPribosylating toxin and NAD complex. Nat. Struct. Biol. 6, 932-936.

Haug, G., Aktories, K., and Barth H. (2004). The host cell chaperone $\mathrm{Hsp} 90$ is necessary for cytotoxic action of the binary iota-like toxins. Infect. Immun. 72, 3066-3068.

Haug, G., Leemhuis, J., Tiemann, D. Meyer, D. K., Aktories, K., and Barth, H. (2003a). The host cell chaperone Hsp90 is essential for translocation of the binary Clostridium botulinum C2 toxin into the cytosol. J. Biol. Chem. 278, 32266-32274.

Haug, G., Wilde, C., Leemhuis, J., Meyer, D. K., Aktories, K., and Barth, H. (2003b). Cellular uptake of Clostridium botulinum C2 toxin: membrane translocation of a fusion toxin requires unfolding of its dihydrofolate reductase domain. Biochemistry 42, 15284-15291.

Heffron, A., and Poxton, I. R. (2007). A PCR approach to determine the distribution of toxin genes in closely related Clostridium species: Clostridium botulinum type $\mathrm{C}$ and $\mathrm{D}$ neurotoxins and $\mathrm{C} 2$ toxin, and Clostridium novyi alpha toxin. J. Med. Microbiol. 56, 196-201.

Heine, K., Pust, S., Enzenmuller, S., and Barth, H. (2008). ADP-ribosylation of actin by the Clostridium botulinum $\mathrm{C} 2$ toxin in mammalian cells results in delayed caspase-dependent apoptotic cell death. Infect. Immun. 76, 4600-4608.

Hilger, H., Pust, S., von Figura, G., Kaiser, E., Stiles, B. G., Popoff, M. R., and Barth, H. (2009). The longlived nature of Clostridium perfringens iota toxin in mammalian cells induces delayed apoptosis. Infect. Immun. 77, 5593-5601.

Hoffmaster, A. R., Hill, K. K., Gee, J. E., Marston, C. K., De, B. K., Popovic, T., Sue, D., Wilkins, P. P., Avashia, S. B., Drumgoole, R., Helma, C. H., Ticknor, L. O., Okinaka, R. T., and Jackson, P. J. (2006). Characterization of Bacillus cereus isolates associated with fatal pneumonias: strains are closely related to Bacillus anthracis and harbor B. anthracis virulence genes. J. Clin. Microbiol. 44, 3352-3360.

Hoffmaster, A. R., Ravel, J., Rasko, D. A., Chapman, G. D., Chute, M. D., Marston, C. K., De, B. K., Sacchi, C. T., Fitzgerald, C., Mayer, L. W., Maiden, M. C., Priest, F. G., Barker, M., Jiang, L., Cer, R. Z., Rilstone, J., Peterson, S. N., Weyant, R. S., Galloway, D. R., Read, T. D., Popovic, T., and Fraser, C. M. (2004). Identification of anthrax toxin genes in a Bacillus cereus associated with an illness resembling inhalation anthrax. Proc. Natl. Acad. Sci. U.S.A. 101, 8449-8454

Holbourn, K. P., Shone, C. C., and Acharya, K. R. (2006). A family of killer toxins. Exploring the mechanism of ADP-ribosylating toxins. FEBS J. 273, 4579-4593.

Houser, B. A., Hattel, A. L., and Jayarao, B. M. (2010). Real-time multiplex polymerase chain reaction assay for rapid detection of Clostridium difficile toxin-encoding strains. Foodborne Pathog. Dis. 7, 719-726.

Jones, D. T., and Keis, S. (2005). "Species and strain identification methods," in Handbook on Clostridia, ed. P. Dürre (Boca Raton, FL: CRC Press), 3-20.

Jung, M., Just, I., van Damme, J., Vandekerckhove, J., and Aktories, K. (1993). NAD-binding site of the C3-like ADP-ribosyltransferase from Clostridium limosum. J. Biol. Chem. 268, 23215-23218. 
Just, I., Geipel, U., Wegner, A., and Aktories, K. (1990). De-ADPribosylation actin by Clostridium perfringens iota-toxin and Clostridium botulinum $\mathrm{C} 2$ toxin. Eur. J. Biochem. 192, 723-727.

Kageyama, A., and Benno, Y. (2000). Coprobacillus catenaformis Gen. Nov., Sp. Nov., a new genus and species isolated from human feces. Microbiol. Immunol. 44, 23-28.

Kaiser, E., Haug, G., Hliscs, M., Aktories, K., and Barth, H. (2006). Formation of a biologically active toxin complex of the binary Clostridium botulinum $\mathrm{C} 2$ toxin without cell membrane interaction. Biochemistry 45, 13361-13368.

Kaiser, E., Kroll, C., Ernst, K., Schwan, C., Popoff, M., Fischer, G., Buchner, J., Aktories, K., and Barth, H. (2011). Membrane translocation of binary actin-ADP-ribosylating toxins from Clostridium difficile and Clostridium perfringens is facilitated by cyclophilin A and Hsp90. Infect. Immun. 79, 3913-3921.

Kaiser, E., Pust, S., Kroll, C., and Barth, H. (2009). Cyclophilin A facilitates translocation of the Clostridium botulinum $\mathrm{C} 2$ toxin across membranes of acidified endosomes into the cytosol of mammalian cells. Cell. Microbiol. 11, 780-795

Kaneuchi, C., Miyazato, T., Shinjo, T., and Mitsuoka, T. (1979). Taxonomic study of helically coiled, sporeforming anaerobes isolated from the intestines of humans and other animals: Clostridium cocleatum sp. nov. and Clostridium spiroforme sp. nov. Int. J. Syst. Bacteriol. 29, 1-12.

Katz, L., Lamont, J. T., Trier, J. S., Sonnenblick, E. B., Rothman, S. W., Broitman, S. A., and Rieth, S. (1978). Experimental clindamycin associated colitis in rabbits. Evidence for toxin-mediated mucosal damage. Gastroenterology 74, 246-252.

Keel, M. K., and Songer, J. G. (2006). The comparative pathology of Clostridium difficile-associated disease. Vet. Pathol. 43, 225-240.

Kim, H., Lee, Y., Moon, H. W., Lim, C. S., Lee, K., and Chong, Y. (2011). Emergence of Clostridium difficile ribotype 027 in Korea. Korean J. Lab. Med. 31, 191-196.

Kimura, K., Kubota, T., Ohishi, I., Isogai, E., Isogai, H., and Fujii, N. (1998). The gene for component-II of botulinum C2 toxin. Vet. Microbiol. 62, 27-34.

Kistner, A., and Habermann, E. (1992). Reductive cleavage of tetanus toxin and botulinum neurotoxin $\mathrm{A}$ by the thioredoxin system from brain. Evidence for two redox isomers of tetanus toxin. Naunyn Schmiedebergs Arch. Pharmacol. 345, 227-234.
Knapp, O., Benz, R., Gibert, M., Marvaud, J. C., and Popoff, M. R. (2002). Interaction of Clostridium perfringens iota-toxin with lipid bilayer membranes. J. Biol. Chem. 277, 6143-6152.

Krantz, B. A., Finkelstein, A., and Collier, R. J. (2006). Protein translocation through the anthrax toxin transmembrane pore is driven by a proton gradient. J. Mol. Biol. 355, 968-979.

Kronhardt, A., Rolando, M., Beltzinger, C., Stefani, C., Leuber, M., Flatau, G., Popoff, M. R., Benz, R., and Lemichez, E. (2011). Crossreactivity of anthrax and C2 toxin: protective antigen promotes the uptake of botulinum C2I toxin into human endothelial cells. PLoS ONE 6, e23133. doi:10.1371/journal.pone.0023133

Kuehne, S. A., Cartman, S. T., Heap, J. T., Kelly, M. L., Cockayne, A., and Minton, N. P. (2010). The role of toxin $\mathrm{A}$ and toxin $\mathrm{B}$ in Clostridium difficile infection. Nature 467, 711-713.

Kurazono, H., Hosokawa, M., Matsuda, H., and Sakaguchi, G. (1987). Fluid accumulation in the ligated intestinal loop and histopathological changes of the intestinal mucosa caused by Clostridium botulinum $\mathrm{C} 2$ toxin in the pheasant and chicken. Res. Vet. Sci. 42, 349-353.

Lacy, D. B., Wigelsworth, D. J., Melnyk, R. A., Harrison, S. C., and Collier, R. J. (2004). Structure of heptameric protective antigen bound to an anthrax toxin receptor: a role for receptor in $\mathrm{pH}$-dependent pore formation. Proc. Natl. Acad. Sci. U.S.A. 101, 13147-13151.

Lang, A. E, Neumeyer, T., Sun, J., Collier, R. J., Benz, R., and Aktories, K. (2008). Amino acid residues involved in membrane insertion and pore formation of Clostridium botulinum C2 toxin. Biochemistry 47, 8406-8413.

Leuber, M., Orlik, F., Schiffler, B., Sickmann, A., and Benz, R. (2006). Vegetative insecticidal protein (Vip1Ac) of Bacillus thuringiensis HD201: evidence for oligomer and channel formation. Biochemistry 45, 283-288.

Li, J., Miyamoto, K., and McClane, B. A. (2007). Comparison of virulence plasmids among Clostridium perfringens type $\mathrm{E}$ isolates. Infect. Immun. 75, 1811-1819.

Lucey, B. P. (2004). William H. Welch, $\mathrm{MD}$, and the discovery of Bacillus welchii. Arch. Pathol. Lab. Med. 128, 1193-1195.

Marvaud, J. C., Smith, T., Hale, M. L., Popoff, M. R., Smith, L. A., and Stiles, B. G. (2001). Clostridium perfringens iota-toxin: mapping of receptor binding and Ia docking domains on Ib. Infect. Immun. 69, 2435-2441.

Marvaud, J. C., Stiles, B. G., Chenal, A. Gillet, D., Gibert, M., Smith, L. A. and Popoff, M. R. (2002). Clostridium perfringens iota toxin. Mapping of the Ia domain involved in docking with $\mathrm{Ib}$ and cellular internalization. J. Biol. Chem. 277, 43659-43666.

Masignani, V., Pizza, M., and Rappuoli, R. (2006). "Molecular, functional and evolutionary aspects of ADPribosylating toxins," in The Comprehensive Sourcebook of Bacterial Protein Toxins, 3rd Edn, eds J. E. Alouf and M. R. Popoff (Paris: Academic Press), 213-244.

Mauss, S., Chaponnier, C., Just, I., Aktories, K., and Gabbiani, G. (1990). ADP-ribosylation of actin isoforms by Clostridium botulinum C2 toxin and Clostridium perfringens iota toxin. Eur. J. Biochem. 194, 237-241.

Metcalf, D. S., Costa, M. C., Dew, W. M. and Weese, J. S. (2010). Clostridium difficile in vegetables, Canada. Lett. Appl. Microbiol. 51, 600-602.

Miller, M., Gravel, D., Mulvey, M., Taylor, G., Boyd, D., Simor, A., Gardam, M., McGeer, A., Hutchinson, J., Moore, D., and Kelly, S. (2010). Health care-associated Clostridium difficile infection in Canada: patient age and infecting strain type are highly predictive of severe outcome and mortality. Clin. Infect. Dis. 50, 194-201.

Miyamoto, K., Yumine, N., Mimura, K., Nagahama, M., Li, J., McClane, B. A., and Akimoto, S. (2011). Identification of novel Clostridium perfringens type E strains that carry an iota toxin plasmid with a functional enterotoxin gene. PLOS ONE 6, e20376. doi:10.1371/journal.pone.0020376

Mogridge, J., Mourez, M., and Collier, R. J. (2001). Involvement of domain 3 in oligomerization by the protective antigen moiety of anthrax toxin. J. Bacteriol. 183, 2111-2116.

Nagahama, M., Hagiyama, T., Kojima, T., Aoyanagi, K., Takahashi, C., Oda, M., Sakaguchi, Y., Oguma, K., and Sakurai, J. (2009). Binding and internalization of Clostridium botulinum C2 toxin. Infect. Immun. 77, 5139-5148.

Nagahama, M., Nagayasu, K., Kobayashi, K., and Sakurai, J. (2002). Binding component of Clostridium perfringens iota-toxin induces endocytosis in Vero cells. Infect. Immun. 70, 1909-1914.

Nagahama, M., Umezaki, M., Oda, M., Kobayashi, K., Tone, S., Suda, T., Ishidoh, K., and Sakurai, J. (2011). Clostridium perfringens iota-toxin $\mathrm{b}$ induces rapid cell necrosis. Infect. Immun. 79, 4353-4360.
Nagahama, M., Yamaguchi, A., Hagiyama, T., Ohkubo, N., Kobayashi, K., and Sakurai, J. (2004). Binding and internalization of Clostridium perfringens iota-toxin in lipid rafts. Infect. Immun. 72, 3267-3275.

Nakamura, S., Serikawa, T., Yamakawa, K., Nishida, S., Kozaki, S., and Sakaguchi, G. (1978). Sporulation and C2 toxin production by Clostridium botulinum type $\mathrm{C}$ strains producing no $\mathrm{C} 1$ toxin. Microbiol. Immunol. 22 591-596.

Nestorovich, E. M., Karginov, V. A., Popoff, M. R., Bezrukov, S. M., and Barth, H. (2011). Tailored $\beta$-cyclodextrin blocks the translocation pores of binary exotoxins from Clostridium botulinum and Clostridium perfringens and protects cells from intoxication. PLoS ONE 6, e23927. doi:10.1371/journal.pone.0023927

O'Conner, J. R., Johnson, S., and Gerding, D. N. (2009). Clostridium difficile infection caused by the epidemic BI/NAP1/027 strain. Gastroenterology 136, 1913-1924.

Ohishi, I. (1983a). Lethal and vascular permeability activities of botulinum C2 toxin induced by separate injections of the two toxin components. Infect. Immun. 40, 336-339.

Ohishi, I. (1983b). Response of mouse intestinal loop to botulinum C2 toxin: enterotoxic activity induced by cooperation of nonlinked protein components. Infect. Immun. 40, 691-695.

Ohishi, I. (1987). Activation of botulinum $\mathrm{C} 2$ toxin by trypsin. Infect. Immun. 55, 1461-1465.

Ohishi, I., Iwasaki, M., and Sakaguchi, G. (1980). Purification and characterization of two components of botulinum C2 toxin. Infect. Immun. 30, 668-673.

Ohishi, I., and Miyake, M. (1985). Binding of the two components of $\mathrm{C} 2$ toxin to epithelial cells and brush borders of mouse intestine. Infect. Immun. 48, 769-775.

Ohishi, I., Miyake, M., Ogura, H., and Nakamura, S. (1984). Cytopathic effect of botulinum C2 toxin on tissue-culture cells. FEMS Microbiol. Lett. 23, 281-284.

Ohishi, I., and Tsuyama, S. (1986). ADPribosylation of nonmuscle actin with component I of $\mathrm{C} 2$ toxin. Biochem. Biophys. Res. Commun. 136, 802-806.

Ohishi, I., and Yanagimoto, A. (1992). Visualizations of binding and internalization of two nonlinked protein components of botulinum C2 toxin in tissue culture cells. Infect. Immun. 60, 4648-4655. 
Papatheodorou, P., Carette, J. E., Bell, G. W., Schwan, C., Guttenberg, G., Brummelkamp, T. R., and Aktories, K. (2011). Lipolysis-stimulated lipoprotein receptor (LSR) is the host receptor for the binary toxin Clostridium difficile transferase (CDT). Proc. Natl. Acad. Sci. U.S.A. 108, 16422-16427.

Perelle, S., Gibert, M., Boquet, P., and Popoff, M. R. (1993). Characterization of Clostridium perfringens iota-toxin genes and expression in Escherichia coli. Infect. Immun. 61, 5147-5156.

Perelle, S., Gibert, M., Bourlioux, P., Corthier, G., and Popoff, M. R. (1997a). Production of a complete binary toxin (actin-specific ADPribosyltransferase) by Clostridium difficile CD196. Infect. Immun. 65, 1402-1407.

Perelle, S., Scalzo, S., Kochi, S., Mock, M., and Popoff, M. R. (1997b). Immunological and functional comparison between Clostridium perfringens iota toxin, C. spiroforme toxin, and anthrax toxins. FEMS Microbiol. Lett. 146, 117-121.

Perrin, B. J., and Ervasti, J. M. (2010). The actin gene family: function follows isoform. Cytoskeleton 67, 630-634.

Popoff, M. R. (2000). "Molecular biology of actin-ADP-ribosylating toxins," in Handbook of Experimental Pharmacology - Bacterial Protein Toxins, Vol. 145, eds K. Aktories and I. Just (Berlin: Springer-Verlag), 275-306.

Popoff, M. R., Milward, F. W., Bancillon, B., and Boquet, P. (1989). Purification of the Clostridium spiroforme binary toxin and activity of the toxin on HEp-2 cells. Infect. Immun. 57, 2462-2469.

Popoff, M. R., Rubin, E. J., Gill, D. M., and Boquet, P. (1988). Actin-specific ADP-ribosyltransferase produced by a Clostridium difficile strain. Infect. Immun. 56, 2299-2306.

Pratt, W. B., and Toft, D. O. (2003). Regulation of signaling protein function and trafficking by the hsp90/hsp70based chaperone machinery. Exp. Biol. Med. 228, 111-133.

Pust, S., Barth, H., and Sandvig, K. (2010). Clostridium botulinum C2 toxin is internalized by clathrin- and Rho-dependent mechanisms. Cell. Microbiol. 12, 1809-1820.

Pust, S., Hochmann, H., Kaiser, E., von Figura, G., Heine, K., Aktories, K., and Barth, H. (2007). A recombinant fusion toxin as a tool to study the cytopathic effects of the actin-ADPribosylating virulence factor $\mathrm{SpvB}$ from Salmonella enterica. J. Biol. Chem. 282, 10272-10282.
Ratts, R., Zeng, H., Berg, E. A., Blue, C., McComb, M. E., Costello, C. E., vanderSpeck, J. C., and Murphy, J. R. (2003). The cytosolic entry of diphtheria toxin catalytic domain requires a host cell cytosolic translocation factor complex. J. Cell Biol. 160, 1139-1150.

Richard, J. F., Mainguy, G., Gibert, M., Marvaud, J. C., Stiles, B. G., and Popoff, M. R. (2002). Transcytosis of iota-toxin across polarized $\mathrm{CaCo}-2$ cells. Mol. Microbiol. 43, 907-917.

Robertson, G. T., Doyle, T. B., Du, Q., Duncan, L., Mdluli, K. E., and Lynch, A. S. (2007). A novel indole compound that inhibits Pseudomonas aeruginosa growth by targeting $\mathrm{MreB}$ is a substrate for MexABOprM. J. Bacteriol. 189, 6870-6881.

Ross, H. E., Warren, M. E., and Barnes, J. M. (1949). Clostridium welchii iota toxin: its activation by trypsin. J. Gen. Microbiol. 3, 148-152.

Saitou, N., and Nei, M. (1987). The neighbor-joining method: a new method for reconstructing phylogenetic trees. Mol. Biol. Evol. 4, 406-425.

Sakaguchi, Y., Hayashi, T., Yamamoto, Y., Nakayama, K., Zhang, K., Ma, S., Arimitsu, H., and Oguma, K. (2009). Molecular analysis of an extrachromosomal element containing the $\mathrm{C} 2$ toxin gene discovered in Clostridium botulinum type C. J. Bacteriol. 191, 3282-3291.

Sakurai, J., and Kobayashi, K. (1995). Lethal and dermonecrotic activities of Clostridium perfringens iota toxin: biological activities induced by cooperation of two nonlinked components. Microbiol. Immunol. 39, 249-253.

Sakurai, J., Nagahama, M., Hisatsune, J., Katunuma, N., and Tsuge, H. (2003). Clostridium perfringens iota-toxin, ADP-ribosyltransferase: structure and mechanism of action. Adv. Enzyme Regul. 43, 361-377.

Sawires, Y. S., and Songer, J. G. (2005). Multiple-locus variable-number tandem repeat analysis for strain typing of Clostridium perfringens. Anaerobe 11, 262-272.

Schering, B., Barmann, M., Chhatwal, G. S., Geipel, U., and Aktories, K. (1988). ADP-ribosylation of skeletal muscle and non-muscle actin by Clostridium perfringens iota toxin. Eur. J. Biochem. 171, 225-229.

Schleberger, C., Hochmann, H., Barth, H., Aktories, K., and Schulz, G. E. (2006). Structure and action of the binary C2 toxin from Clostridium botulinum. J. Mol. Biol. 364, 705-715.

Schmid, A., Benz, R., Just, I., and Aktories, K. (1994). Interaction of
Clostridium botulinum $\mathrm{C} 2$ toxin with lipid bilayer membranes: formation of cation-selective channels and inhibition of channel function by chloroquine and peptides. J. Biol. Chem. 269, 16706-16711.

Schmid, F. X. (1993). Prolyl isomerase: enzymatic catalysis of slow proteinfolding reactions. Annu. Rev. Biophys. Biomol. Struct. 22, 123-142.

Schwan, C., Nolke, T., Kruppke, A. S., Schubert, D. M., Lang, A. E., and Aktories, K. (2011). Cholesterol- and sphingolipid-rich microdomains are essential for microtubule-based membrane protrusions induced by Clostridium difficile transferase CDT. J. Biol. Chem. 286, 29356-29365.

Schwan, C., Stecher, B., Tzivelekidis, T. van Ham, M., Rohde, M., Hardt, W. D., Wehland, J., and Aktories, K. (2009). Clostridium difficile toxin CDT induces formation of microtubule-based protrusions and increases adherence of bacteria. PLoS Pathog. 5, e1000626. doi:10.1371/journal.ppat.1000626

Scobie, H. M., Rainey, G. J., Bradley, K. A., and Young, J. A. (2003). Human capillary morphogenesis protein 2 functions as an anthrax toxin receptor. Proc. Natl. Acad. Sci. U.S.A. 100, 5170-5174.

Sellman, B. R., Nassi, S., and Collier, R. J. (2001). Point mutations in anthrax protective antigen that block translocation. J. Biol. Chem. 276, 8371-8376.

Simpson, L. L. (1982). A comparison of the pharmacological properties of Clostridium botulinum type $\mathrm{C} 1$ and C2 toxins. J. Pharmacol. Exp. Ther. 223, 695-701.

Simpson, L. L., Stiles, B. G., Zepeda, H., and Wilkins, T. D. (1989). Production by Clostridium spiroforme of an iotalike toxin that possesses mono(ADP-ribosyl)transferase activity: identification of a novel class of ADP-ribosyltransferases. Infect. Immun. 57, 255-261.

Smith, H. (2002). Discovery of the anthrax toxin: the beginning of studies of virulence determinants regulated in vivo. Int. J. Med. Microbiol. 291, 411-417.

Songer, G. L. (2005). "Clostridial diseases in domestic animals," in Handbook on Clostridia, ed. P. Dürre (Boca Raton, FL: CRC Press), 527-545.

Sterthoff, C., Lang, A. E., Schwan, C., Tauch, A., and Aktories, K. (2010). Functional characterization of an extended binding component of the actin-ADP-ribosylating $\mathrm{C} 2$ toxin detected in Clostridium botulinum strain (C) 2300. Infect. Immun. 78, 1468-1474.
Stiles, B. G., Hale, M. L., Marvaud, J. C., and Popoff, M. R. (2000). Clostridium perfringens iota toxin: binding studies and characterization of cell surface receptor by fluorescenceactivated cytometry. Infect. Immun. 68, 3475-3484.

Stiles, B. G., Hale, M. L., Marvaud, J. C., and Popoff, M. R. (2002). Clostridium perfringens iota toxin: characterization of the cell-associated iota b complex. Biochem. J. 367, 801-809. Stiles, B. G., and Wilkins, T. D. (1986). Purification and characterization of Clostridium perfringens iota toxin: dependence on two nonlinked proteins for biological activity. Infect. Immun. 54, 683-688.

Sugii, S., and Kozaki, S. (1990). Hemagglutinating and binding properties of botulinum C2 toxin. Biochim. Biophys. Acta 1034, 176-179.

Sundriyal, A., Roberts, A. K., Shone, C. C., and Acharya, K. R. (2009). Structural basis for substrate recognition in the enzymatic component of ADP-ribosyltransferase toxin CDTa from Clostridium difficile. J. Biol. Chem. 284, 28713-28719.

Tamura, K., Dudley, J., Nei, M., and Kumar, S. (2007). MEGA4: molecular evolutionary genetics analysis (MEGA) software version 4.0. Mol. Biol. Evol. 24, 1596-1599.

Taylor, M., Navarro-Garcia, F., Huerta, J., Burress, H., Massey, S., Ireton, K., and Teter, K. (2010). Hsp90 is required for transfer of the cholera toxin Al subunit from the endoplasmic reticulum to the cytosol. J. Biol. Chem. 285, 31261-31267.

Thakur, S., Putnam, M., Fry, P. R., Abley, M., and Gebreyes, W. A (2010). Prevalence of antimicrobial resistance and association with toxin genes in Clostridium difficile in commercial swine. Am. J. Vet. Res. 71, 1189-1194.

Thean, S., Elliott, B., and Riley, T. (2011). Clostridium difficile in horses in Australia - a preliminary study. J. Med. Microbiol. 60, 1188-1192.

Tsuge, H., Nagahama, M., Nishimura, H., Hisatsune, J., Sakaguchi, Y., Itogawa, Y., Katunuma, N., and Sakurai, J. (2003). Crystal structure and sitedirected mutagenesis of enzymatic components from Clostridium perfringens iota-toxin. J. Mol. Biol. 325, 471-483.

Tsuge, H., Nagahama, M., Oda, M., Iwamoto, S., Utsunomiya, H., Marquez, V. E., Katunuma, N., Nishizawa, M., and Sakurai, J. (2008). Structural basis of actin recognition and arginine ADP-ribosylation by Clostridium perfringens l-toxin. Proc. Natl. Acad. Sci. U.S.A. 105, 7399-7404. 
Uematsu, Y., Kogo, Y., and Ohishi, I. (2007). Disassembly of actin filaments by botulinum $\mathrm{C} 2$ toxin and actin-filament-disrupting agents induces assembly of microtubules in human leukaemia cell lines. Biol. Cell 99, 141-150.

van Damme, J., Jung, M., Hofmann, F., Just, I., Vandekerckhove, J., and Aktories, K. (1996). Analysis of the catalytic site of the actin ADPribosylating Clostridium perfringens iota toxin. FEBS Lett. 380, 291-295.

Vandekerckhove, J., Schering, B., Bärmann, M., and Aktories, K. (1988). Botulinum C2 toxin ADPribosylates cytoplasmic $\beta / \gamma$-actin in arginine 177. J. Biol. Chem. 263, 696-700.

Vieira, F. S., Correa, G., Einicker-Lamas, M., and Coutinho-Silva, R. (2010). Host-cell lipid rafts: a safe door for micro-organisms? Biol. Cell 102, 391-407.

Vollmer, W. (2006). The prokaryotic cytoskeleton: a putative target for inhibitors and antibiotics? Appl. Microbiol. Biotechnol. 73, 37-47.

Wandinger, S. K., Richter, K., and Buchner, J. (2008). The Hsp90 chaperone machinery. J. Biol. Chem. 282, 18473-18477.

Wang, Y., Addess, K. J., Chen, J., Geer, L. Y., He, J., He, S., Lu, S., Madej, T., Marchler-Bauer, A., Thiessen, P. A., Zhang, N., and Bryant, S. H. (2007). MMDB: annotating protein sequences with Entrez's 3Dstructure database. Nucleic Acids Res. 35, D298-D300.

Welch, W. H., and Flexner, S. (1896). Observations concerning Bacillus aerogenes capsulatus. J. Exp. Med. 1, 5-45.

Wertman, K. F., and Drubin, D. G. (1992). Actin constitution: guaranteeing the right to assemble. Science 258, 759-760.

Wesche, J., Malecki, J., Wiedlocha, A., Skjerpen, C. S., Claus, P., and Olsnes, S. (2006). FGF-1 and FGF-2 require the cytosolic chaperone Hsp90 for translocation into the cytosol and the cell nucleus. J. Biol. Chem. 281, 11405-11412.

Zhang, S., Finkelstein, A., and Collier, R. J. (2004). Evidence that translocation of anthrax toxin's lethal factor is initiated by entry of its $\mathrm{N}$ terminus into the protective antigen channel. Proc. Natl. Acad. Sci. U.S.A. 101, 16756-16761.

Zornetta, I., Brandi, L., Janowiak, B., Dal Molin, F., Tonello, F., Collier, R. J., and Montecucco, C. (2010). Imaging the cell entry of the anthrax oedema and lethal toxins with fluorescent protein chimeras. Cell. Microbiol. 12, 1435-1445.

Zuckerkandl, E., and Pauling, L. (1965). "Evolutionary divergence and convergence in proteins," in Evolving Genes and Proteins, eds V. Bryson and H. J. Vogel (New York: Academic Press), 97-166.

Zuehlke, A., and Johnson, J. L. (2010). Hsp90 and co-chaperones twist the functions of diverse client proteins. Biopolymers 93, 211-217.

Conflict of Interest Statement: The authors declare that the research was conducted in the absence of any commercial or financial relationships that could be construed as a potential conflict of interest.

Received: 28 September 2011; accepted: 10 November 2011; published online: 01 December 2011.

Citation: Stiles BG, Wigelsworth DJ, Popoff MR and Barth $H$ (2011) Clostridial binary toxins: iota and C2 family portraits. Front. Cell. Inf. Microbio. 1:11. doi: 10.3389/fcimb.2011.00011 Copyright (c) 2011 Stiles, Wigelsworth, Popoff and Barth. This is an open-access article distributed under the terms of the Creative Commons Attribution Non Commercial License, which permits noncommercial use, distribution, and reproduction in other forums, provided the original authors and source are credited. 